\title{
Origin and phylogeny of velatid asteroids (Echinodermata, Neoasteroidea) - new evidence from the Jurassic
}

\author{
Andy S. Gale ${ }^{1}$
}

Abstract Asteroids of the Jurassic-Recent group of the Velatida evolved during the Late Triassic or Early Jurassic from the family Tremasteridae, previously placed, as a subfamily, in the Asterinidae. Tremasterids and velatids are characterized by the possession of interradial ducts that are lined with chevron ossicles, which are used to brood young. Here, the clade Chevronida is introduced for this group. Fossil tremasterids are represented by the genus Mesotremaster from the Bajocian and Oxfordian of Switzerland. A series of morphologically intermediate forms link tremasterids to the Jurassic-extant family Korethrasteridae, including the Early Jurassic (Hettangian) Protremaster, and Thuyaster fontenoillensis gen. et sp. nov. Korethrasterids, in turn, gave rise to the present-day "cushion stars" or "slime stars" (Pterasteridae), highly derived asteroids, which brood young beneath a canopy, are protected by copious mucus secretion, and have a complex respiration system. It is concluded that basal Pterasteridae were present in the Bajocian (Middle Jurassic; Longwyaster delsatei gen. et sp. nov.), and that forms very similar to extant species were present by the lower Oxfordian (Hansaster [gen. nov.] trimbachensis, Propteraster amourensis gen. et sp. nov.). The suggestion, based upon molecular studies, that pterasterids are basal to the neoasteroids, has been tested using morphology and the fossil record, and is found to be incorrect.

Keywords Jurassic · velatid ·asteroid · phylogeny

Andy S. Gale

andy.gale@port.ac.uk

1 School of Earth and Environmental Sciences, University of Portsmouth, Burnaby Building, Burnaby Road, Portsmouth PO13QL, UK 


\section{Introduction}

The phylogenetic relationships of post-Palaeozoic asteroids have a long history of controversy, starting with the opposing views presented by McBride (1921) and Mortensen (1921) as to the primitive condition. McBride (1921) argued that the absence of brachiolaria larvae in paxillosid development, in addition to the absence of suckers on the tube feet and lack of an anus, was a result of secondary loss, "....... so far from being primitive, are quite a modern development of Asteroid structure in the Ophiuroid direction". Mortensen, on the other hand, believed that the absence of brachiolaria larvae was a primitive feature.

Subsequently, views have polarized into two camps. Following Mortensen, it has been argued that paxillosid asteroids are basal to the neoasteroids (Gale 1987, 2011a, 2012; Heddle 2012), based upon developmental and morphological evidence. The alternative scenario was provided by Blake $(1987,1988)$, who built upon the ideas of McBride, that forcipulatid asteroids are basal to the group, and that the condition in paxillosids therefore represents secondary loss of brachiolaria larvae, suckered tube feet, eversible stomachs and simplification of the pedicellariae (Gale 2011a; Blake 1987,1988).

The fossil record provides little or no support for either hypothesis, because derived members of extant ordinal and familial groups appear almost simultaneously in the Lower Jurassic (Gale 2011a). The Triassic record of asteroids remains ambiguous; although these are clearly neoasteroids, assignment to extant orders and families does not appear to be possible and they might represent a separate early radiation of neoasteroids.

Recently, molecular studies (Janies et al. 2011; Feuda and Smith 2015) have placed a completely different group, the velatids, as basal to all other extant asteroids. Velatids comprise a highly derived group of predominantly deep-sea asteroids including three families, the Pterasteridae, Myxasteridae and Korethrasteridae (Gale 2011a).

Korethrasterids, represented by three extant genera, are rather uncommon, predominantly bathyal asteroids (Clarke and Downey 1992). Pterasterids are common components of bathyal and abyssal faunas, and the family includes seven genera (Diplopteraster, Hymenaster, Pteraster, Calyptreaster, Euretaster, Benthaster, Hymenasteroides) and about 110 species. Myxasterids are rare, deep-water, multi-armed asteroids represented by nine species placed in three genera (Myxaster, Pythonaster, Asthenactis; Mah et al. 2012). Fossil pterasterids are known from the Upper Cretaceous (CampanianMaastrichtian) of Europe (Villier et al. 2004), and a basal pterasterid (Savignaster wardi Gale, 2011) was described from the Oxfordian of France (Gale 2011a, b). 
The origin of the korethrasterid-pterasterid clade was traced back to the Early Jurassic (Hettangian) species Protremaster uniserialis Smith and Tranter, 1985, which is morphologically intermediate between the extant asterinid (tremasterine) Tremaster and the extant korethrasterid Korethraster (Gale 2012). It thus appears, from a morphological understanding, that the velatid clade is derived from an asterinid taxon. New Jurassic discoveries from France now permit further study of the evolution of this clade; these are documented in this paper.

\section{Pterasterids - basal neoasteroids?}

Surviving basal representatives of groups not uncommonly show highly derived morphologies. The living monotreme mammal Ornithorhynchus, the Duck-billed Platypus, is a well-known example, in which the dentition is lost in the adult, replaced by a duck-like beak and the tail is flattened and beaver-like. However, the plesiomorphic position of the animal is not in doubt, as it is egg-laying, has mammary glands but no nipples, and the skeleton shows a mosaic of plesiomorphic mammalian features (Griffiths 1978). Study of the genome of Ornithorhynchus (Warren et al. 2008) confirms and elucidates details of this mosaic of plesiomorphic (reptilian) and derived mammalian features.

In the neoasteroids, paxillosids occupy an equivalent position to monotremes in terms of morphology and developmental history. The evidence for paxillosid plesiomorphy was described in detail by Gale (2011a), including numerous skeletal features (presence of an external face on odontophore, morphology of circumoral ossicles, adamb-adamb articulation, only elementary pedicellariae present, marginal position of madreporite), soft tissue features (lack of suckers on tube feet, simple gut, lacking anus) and developmental features (Early Madreporic Mode of development, absence of brachiolaria larvae). Initial molecular studies tended to support the basal position of the paxillosids (Wada et al. 1996). However, this is contradicted by more extensive molecular evidence; Mah and Foltz (2011a, b) identified a group including the Forcipulatacea and Velatida as basal to all other extant asteroids, and placed the Paxillosida as basal to the remaining asteroid groups. The detailed analysis of Feuda and Smith (2015) unambiguously identifies the velatid family Pterasteridae (two genera studied by them; Pteraster and Hymenaster) as basal to all other living asteroids, following Janies et al. (2011), with considerable statistical support. There is thus a striking conflict between the morphological and molecular 
evidence, and it becomes interesting and important to examine the morphology, ancestry, phylogeny and fossil record of the pterasterids (Gale 2012).

The anatomy and physiology of pterasterid asteroids has received significant attention, based particularly upon the few species which live in shallow-marine habitats and can therefore be kept in aquaria. Pteraster tesselatus Ives, 1888, the Slime Star, is found on the coast of the northeast Pacific, and has been widely studied (Fisher 1911; Chia 1966; Nance and Braithwaite 1979, 1981; McEdward 1995). The development of brooding in Pteraster militiaris (O.F. Müller, 1776) from the northeastern Canadian coast has also been studied (McClary and Mladenov 1990). The morphology of Pterasteridae is highly derived; members of this family are characterized particularly by the possession of an enveloping muscular canopy (Fig. 1), supported by spines, which at least in some species is known to be a brood chamber where the young are retained to a considerable size, to emerge eventually by rupturing the membrane (McClary and Mladenov 1990). Additionally, pterasterids possess a complex musculo-skeletal system which allows them to respire by inhalation and exhalation of seawater (Fig. 2; Nance and Braithwaite1981). Certain pterasterids have a unique embryological development (McEdward 1995) and produce a larva called a mesogen. Pterasterids are protected by copious mucous production from specialised cells in the epithelium lining the canopy, hence the names slime or snot stars in North America (Nance and Braithwaite 1979, 1981). The skeleton of pterasterids is highly derived, being reduced to a meshwork of delicate ossicles (Figs 1, 3; Danielssen and Koren 1884, pl. 13; Sladen 1889; Fisher 1911, pl. 115; Gale 2011a, b, 2012). The detailed modification includes:

- the abactinal surface is a delicately constructed reticulum of modified abactinal ossicles called megapaxillae, with tall pedicels each carrying a crown of elongated spines supporting the canopy (Figs 1-4).

- imbricated abactinal and interradial chevron ossicles, united by muscles with each other and the adjacent abactinal ossicles; these contract to reduce the coelomic volume and cause the papulae to swell (Figs $2 A, B, 4 F, G, 5 K, L)$.

- a muscular canopy enveloping the entire body, except for the mouth and ambulacral grooves, perforated by closeable pores called spiraculae. 
- oval apertures between each adambulacral, each opened and closed by a guard (apertural) spine (Figs 1G, H).

- an opening in the centre of the abactinal disc (the osculum), opened and closed by an array of spines united by a membrane. The spines are borne upon tall primary radial ossicles (Figs 1-4), and the structure is closed by contraction of muscles which attach to the inside of the spine bases inserting into a cavity on the proximal surface of the primary radials (see below).

Many of the ossicles of pterasterids are highly distinctive (ambs, adambs, orals, circumorals, chevrons and abactinals) and permit the certain identification of fossil pterasterid taxa (Villier et al. 2004; Gale 2011a, b), and recognition of the appearance of synapomorphies exclusive to the family.

In the almost exclusively abyssal Hymenaster (Figs 3, 5A-D) there is an overall reduction of the skeletal elements already reduced in Pteraster. 1) the chevron ossicles are reduced in number to two in each interradius (Fig. 3F) and 2) the abactinal skeleton is very slender (Fig. 3E, G). In basal forms, such as H. perissonotus Fisher, 1911 (Fig. 3B, $F, G)$, the abactinal ossicles still form a loose, open reticulum. In more derived taxa, such as $H$. pellucidus Thomson, 1873 , the abactinals are reduced to two rows on each side of the radius (Fig. 3C-E) and the radials distal to the primary ossicle are absent. The adradial row of abactinals is supported by processes from the adambulacrals (Fig. 3F). The adambulacrals and ambulacrals themselves also differ significantly from the condition in Pteraster (Fig. 5A-D). The more actinal adambulacral spines are reduced to three, lack a uniting membrane, and are deeply inset on the surface of the adambulacral. The apertural spine is large and flat, and the actinolateral spine large and very powerfully muscularised (Fig. 5D). The ambulacrals (Fig. 5C) have very elongated distal flanges. 
The Myxasteridae have been assigned to the Velatida (Blake 1987, Blake 1996; Clarke and Downey 1992). These are multi-armed asteroids, in which the abactinal skeleton consists of a reticulum of small ossicles, some of which bear a fascicle of spines (Fig. 2C). Chevron plates are present in the interradii. The form of the abactinal skeleton allows one to infer that Myxasterids probably evolved from a taxon close to Peribolaster, by acquisition of numerous arms. Myxasterids are not included in the cladistic analysis (below), but the molecular phylogeny of Mah and Foltz (2011a, Fig. 2) places Asthenactis fisheri Alton, 1966 within the Velatida, as sister taxon to the pterasterid Euretaster. A number of poorly known Jurassic asteroids (Decacuminaster, Xandarosaster, Plesiastropecten) referred to the Velatida by Villier et al. (2009) are also not considered here.

If pterasterids were indeed basal neoasteroids, they would be expected to lack some synapomorphies of the more derived crown group, and retain plesiomorphic characters from stem group asteroids (i.e., Palaeozoic forms). Neither of these cases is true, and pterasterids are highly derived, autapomorphic neoasteroids which evolved from the less specialised Korethrasteridae (Gale 2011a, 2012, supported by molecular evidence, see Mah and Foltz 2011a fig.1). It is therefore necessary to look at the origins of the korethrasterids.

\section{Morphology of the Tremasterinae and Velatida}

Overall construction. In Asterina and Tremaster, the arms are short and the interradius is broad; the outline is rounded in Tremaster (Fig. 6A, B), with moderately produced arms in Asterina (Fig. 5E, F). The body is flat in Asterina, domed in Tremaster, and in both the abactinal surface is very robustly constructed of numerous small, imbricating, diagonally 
arranged ossicles; spines are short and thorny in Tremaster, granular in Asterina, and largely confined to the margins of the ossicles. Numerous small actinals are present. In Korethraster (Fig. 7A, B, I) the abactinal surface is also made up of tile-like abactinals, but the overall construction is delicate, and each abactinal plate bears a fascicle of long, glassy spines (Fig. 7A, B); the actinal surface is made up entirely of the adambulacrals. In Remaster (Fig. 7E, G) the abactinal ossicles form a reticulum with intervening gaps for papulae, and the spines of each fascicle are united by a membrane. The abactinal skeleton is openly reticulate in Peribolaster (Fig. 7C) and Pteraster (Fig. 1A-D), and in pterasterids a muscular canopy, supported by abactinal spines borne on tall pedicels, envelops the entire body, except for the mouth and ambulacral groove. This is apparently absent in Amembranaster (Golotsvan 1998).

Abactinals. In asterinids (e.g., A. gibbosa), the abactinal ossicles are all small, tile-like and strongly imbricated, with papular openings between the plates (Fig. 5E). The basic construction of Tremaster is similar (Fig. 6A), but the primary radials, interradials and centrale are enlarged (Fig. 4A), and openings for the interradial ducts are found distal to the primary interradials. The abactinals are similar in Protremaster (Fig. 6E), but many plates have a central boss which carried a fascicle of spines, similar to the situation in the living Korethraster (Fig. 7A, I). In Remaster (Figs 4C, 7G), papular openings between the abactinals are enlarged, and the plates form a trellis-like mesh; the spine-bearing central bosses are proportionately larger. The mesh is more open in Peribolaster (Fig. 7C, D) and the abactinals are co-joined by smaller intermediate linking ossicles (Fig. 4D).

In extant pterasterids (Figs 1A-D, 4I) the abactinals all bear a tall pedicel which carries a fan of delicate spines to support the canopy (Figs 3, 8D, O, P, R). In Pteraster and many fossil forms, the abactinals imbricate over each other and the chevron plates, and are cojoined by muscles (Fig. 5J-L) which contract to reduce the coelomic space during 
respiration (Fig. 2; see below). The reticulate abactinal mesh has broad openings for papulae. In Hymenaster perissonotus (Fig. 3B, G) the arrangement of abactinal ossicles is very similar to that in Pteraster (compare with Fig. 4F, I) although individual plates are more slender and the meshwork is more open. Hymenaster pellucidus, on the other hand (Fig. 4C-E), has entirely lost the radial row of plates, and the abactinals are reduced to two rows in each radius, of which the abradial row is larger. In Hymenaster, abradial processes from the adambulacrals contact the abactinal ossicles.

Primary radial ossicles (pr) are highly specialised in pterasterids (e.g., Villier et al. 2004), and perform the function of supporting the osculum (Fig. 4E-G, I). This involves specifically the articulation of the webbed spines closing the osculum and insertion of the powerful muscles which pull the spines down to close the structure (Fig. 2).

Primary radial ossicles of extant pterasterids (Fig. 9L-O) have a uniform basic structure, comprising a basal portion (bp) which carries four processes, articulating, respectively, with the adjacent pr (proximal processes, $p p$ ) and two primary pir (distal processes, $d p)$. Two distinct cavities which serve for muscle insertion are present at the base of the proximal processes (proximal cavities). Arising from the basal portion is a vase-shaped column, a highly modified pedicel, which is divided into a narrow basal neck, and an expanded abactinal head which has a flattened or slightly concave abactinal surface. The column is triangular in outline in proximal and distal profiles, and is distinctively constructed from vertical interconnected sheets of perforate stereom, which appear on the surface of ossicle as length-parallel trabeculae united by cross-struts. The abactinal surface of the column carries numerous closely spines, arranged in a marginal ring, and the muscles which pull these spines down are inserted on the proximal surface of the column. A process called a proximal spur contains a concavity into which the longest muscle fibres insert. 
There is considerable variation in morphology of the pr among extant and fossil pterasterids (Fig. 9), which is discussed in the Systematic Palaeontology section (below).

Primary interradial ossicles. In Tremaster, the primary interradial ossicles (pir) are flat, polygonal plates which form a ring surrounding the centrale and periproct (Fig. 4A), and are separated from the interradial channel by a pair of plates. In Korethraster, the pir are similar but separated by the primary radials (Fig. 4B), such that pir and pr alternate; distally, they contact the first (abactinal) pair of chevron ossicles. This basic arrangement is present in all korethrasterids and pterasterids (Fig. 4B-I), and in Peribolaster and pterasterids, the pir have five processes (Fig. 14E, F; compare Gale 2011a, pl. 25, figs 10, $11,14,15,18,19)$ of which the single median, distal process articulates with the first chevron ossicles. The proximal pair contact the distal processes of the pr (Fig. 4E, F), the distal pair the first two abactinal ossicles.

Chevron ossicles. In Tremaster, the interradial ducts which extend from the abactinal surface to the edge of the mouth frame (Figs 4J, 6A-D) are floored by seven, symmetrical pairs of flat, triangular ossicles which articulate across the interradius (Fig. 6C). These articulate loosely with the inner surface of the abactinal ossicles, and spaces between the chevrons are covered with a membrane, such that the structure forms a tube. The most actinal two pairs of chevrons are united with the actinal opening of the duct by a chimneylike construction of oval ossicles. The chevron ossicles are not visible through the small, oval actinal opening in Tremaster, but in Mesotremaster zbindeni (Figs 4K, 6F) five plate pairs are seen between the actinal ossicles in the interradius, and four in Protremaster uniserialis (Figs 4L, 6E). However, in the latter form, the abactinal ossicles clearly cover the duct completely (see bottom portion of Fig. 6E). In the extant Korethraster (Fig. 4B), Remaster (Figs 4E, 7G, H), and Peribolaster (Fig. 4D), the abactinals along the interradius 
have separated, such that the ducts have become $V$-shaped interradial furrows, floored by chevron ossicles, running from the distal border of the primary interradial ossicles to the odontophores. The chevron ossicles have bifid lateral processes, each of which articulates with an abactinal. In Pteraster, there are ten pairs of chevron ossicles in each interradius; these have four long processes (Fig. 10N, R - two running to the adjacent chevrons, two to abactinals) and over the chevrons imbricate strongly (Figs 1, 4F). In Hymenaster (Fig. 3F), the chevron ossicles are slender and reduced to two per interradius. Chevron ossicles evolved from ossicles of the interradial septum, which is attached to the interior interradius, abactinal to the actinal ossicles in genera such as Asterina.

Actinals and marginals. In the asterinids Asterina, Tremaster and Mesotremaster (Figs 5F, 6B) numerous small actinal ossicles, forming well-defined rows, run from the adambulacrals to the margin and make up the broad interareas. Those in Asterina are imbricated, short and tile-like, and in Tremaster and Mesotremaster they are more elongated and bear short thorny spines (Fig. 6A, B, D, F). Actinals are lost in all korethrasterids and pterasterids, and the actinal surface is made up entirely of adambulacrals. Marginal ossicles in Asterina and Tremaster are tiny and inconspicuous, and the inferomarginals alone form the interradial margins (Clark and Downey 1992). Marginals are absent in all korethrasterids and pterasterids (Gale 2011a).

Ambulacral groove - adambulacrals. The homologies of adambulacrals in asterinids, korethrasterids and pterasterids were discussed and figured by Gale (2011a, text-fig. 11G, H, J; pl. 9, figs 8-12). In summary, the adradial portions of the ossicles are broadly similar in structure, with articulations ada1a and ada1b, plus the interadambulacral muscle (adadm) present, and ada2-3 forms a crescentic band across the ossicle. However, in korethrasterids and pterasterids, the adambulacrals are broad, imbricate strongly and an 
abradial process, the adambulacral extension (adex), is present, which bears a large actinolateral spine on its lateral border (Fig. 1G, H). In korethrasterids, the adex is broad and may carry several spines (Fig. $11 \mathrm{~K}, \mathrm{~S}$ ). An additional articulation surface, the adexa, is present in Tremaster, korethrasterids and many pterasterids (Fig. $11 \mathrm{~J}-\mathrm{L}, \mathrm{R}-\mathrm{T}$ ). The adambulacrals of pterasterids are highly modified, because of their function in respiratory movements. An additional muscle (adexm) is present on the adambulacrals of pterasterids (Fig. $11 \mathrm{~K}, \mathrm{~T}$ ), which, using the adexa as a fulcrum, causes successive adambulacrals to rotate against each other by its contraction. The adambs of pterasterids are flattened obliquely, and the margin bears bases for adambulacral spines which are co-joined by a membrane, the adsm (Fig. 1H). The most abradially positioned adambulacral spine (aps) forms an apertural spine which has an epithelial flap which covers the aperture in the membrane which is present between each adamb, during the deflation phase of the respiratory cycle (Fig. 2). Adambulacrals of Hymenaster (Fig. 5A, B, D) are elongated, lack an adex, and the three adambulacral spines are closely spaced on the surface of the plate, lacking a co-joining membrane. The actinolateral spine is large and has a powerful muscle. The apertural spine is also well developed (Fig. 5D).

Ambulacral groove - ambulacrals. Homologies of asterinid, korethrasterid and pterasterid ambulacrals were discussed and figured by Gale (2011a, text-fig. 9). The ambulacral head is flattened, triangular and imbricates strongly over the adjacent, proximal ambulacral (Figs $13 \mathrm{D}, \mathrm{O}, 14 \mathrm{Q}, 15,16)$. In korethrasterids and pterasterids, there is also a short distal winglike flange (df) on the adambulacral head, which bears an additional interambulacral muscle (Figs 8B, C, I, Q, 11O). This wing is elongated in Hymenaster (Fig. 5C).

Mouth frame. The oral ossicles of asterinids, korethrasterids and pterasterids are similar in shape, construction and spination; the robust body of the plate is square to rectangular, 
and the apophyse is tall and upright with a deep groove for the ring vessel (Gale 2011a, text-figs 17A, D, E, 18B, C). The outer (radial) faces of the orals bear a swollen proximal rim that carries a row of oral spines, and one to several suboral spines are attached to low mounds on the outer surface. The orals of these families are quite different from those of all other neoasteroids (see Gale 2011a, text-figs 16, 17; pls 13, 14). The circumorals of this group are also highly distinctive (Gale 2011a, text-fig. 19), as the proximal circumoral process is very short, and the distal process elongated and narrow. The short pcp corresponds with the tall apophyse on the oral ossicle. The odontophore of Tremaster, korethrasterids and pterasterids is also morphologically distinctive; it is polygonal in outline, and the abactinal face bears four facets for articulation with the oral ossicle (Fig. 11E-G). The external face bears articular structures which contact the most actinally positioned chevron ossicles (Figs 10C, E, 11D).

\section{Origin of the Velatida}

The concept of the Velatida, as used here, follows Gale (2011a), and does not include the Solasteridae, in contrast to Blake (1987). The Early Jurassic genus Tropidaster was considered by Blake (1996) to fall within the velatid clade, and was identified by him as basal to the Korethrasteridae, Pterasteridae, Myxasteridae and Caymanostellidae (Blake 1996 Fig. 1). Abundant new material of Tropidaster is now available from the Pliensbachian of northern France (Thuy et al. 2011), which permits a detailed analysis of the ossicle morphology of this genus. Tropidaster has short arms, acute interradii (Fig. 2

E) and the actinal surface is made up of short, broad adambulacrals which bear a transverse row of serrated spines (Fig. 2D,F,G; Thuy et al. 2011 Fig. 5g,h). The abactinal surface is constructed of paxilliform ossicles (Thuy et al. 2011 Fig. 5g), and interradial chevron plates are absent. Closely spaced, flat-topped primary interradials are present (Blake 1996 PI. 1 Fig. 7). The morphology of the oral ossicles places Tropidaster within the 
asterinid lineage, albeit as a highly derived, autapomorphic form and the absence of chevron ossicles, effectively removes it from the ancestry of the velatids, and it is therefore not included in the cladistic analysis (below).

The asterinid subfamily Tremasterinae is represented in present-day seas by a single species, Tremaster mirabilis Verrill, 1879, which has a global distribution on rocky substrates in deep water (Fig. 6A-D; Jangoux 1982; Clark and Downey 1992). The species has a rounded outline, a domed, concavo-convex form and, uniquely, has calcified internal interradial ducts leading from five openings on the abactinal surface (adjacent to the primary interradial ossicles) to open on the actinal surface close to the oral ossicles (Fig. 4J). The ducts are used to brood young (Jangoux 1982) and are floored by paired interradial rows of I- and Y- shaped chevron ossicles (Gale 2011a, text-fig. 2; Gale 2012). The morphological position of Tremaster mirabilis within the Asterinidae is supported by molecular evidence (Mah and Foltz 2011b fig. 2) as sister taxon to the genera Nepanthia and Tarachaster. Tremasterines are represented in the Jurassic by a number of species, including Mesotremaster felli Hess, 1972 (Bajocian of the Aargauer Jura, Switzerland) and M. zbindeni Hess, 1981 (Fig. 6F, Oxfordian of the Berner Jura, Switzerland). These species are remarkably close to the extant $T$. mirabilis in overall construction (broad, short adambulacrals, bearing a single row of spine bases, numerous short actinals with thorny spines, robust, imbricating abactinals), but the actinal openings of the interradial ducts (adjacent to the oral ossicles) are more elongated in Mesotremaster, and the chevron plates are clearly visible through these (Fig. 4K).

Protremaster uniserialis Smith and Tranter, 1985 (Figs 4L, 6E) from the Sinemurian (Lower Jurassic, 195-190 Ma) of Antarctica is in some ways a typical tremasterine (i.e., short arms, broad interradial areas; tile-like, imbricating, abactinal ossicles; presence of chevron plates), but it also shows remarkable similarities to the living Korethraster hispidus 
Thomson (Fig. 7A, B, I), a boreal Atlantic species belonging to the velatid family Korethrasteridae (Clark and Downey 1992; Gale 2011a, text-fig. 25). These include:

- the first adambulacrals are narrow, the others are short, broad and curved, extending laterally to the ambitus and carrying two to three rows of large spine attachment sites (Fig. 5B, C).

- the interradial ducts are opened actinally, to expose a groove formed by the chevron plates (Figs 4l, 6E).

- actinal and marginal ossicles are lost or (less probably) fused with the adambulacrals, which are very broad and form the entire actinal surface the asteroid.

- large, flared, flattened actinolateral spines are present, attached to the adambulacral extensions.

- the abactinal ossicles carry a raised attachment site for a fascicle of spines (compare Figs $6 \mathrm{E}$ and $7 \mathrm{l})$.

However, the interradial chevron ossicles are not exposed abactinally in Protremaster but are covered by abactinal ossicles (Fig. 6E). The Early Jurassic $P$. uniserialis thus presents a form which is morphologically intermediate between an asterinid (tremasterine) and a velatid (korethrasterid). This is significant because korethrasterids are stem group to the highly derived Pterasteridae (Gale 2011a), and Protremaster therefore appears to be basal to this important modern deep-sea group. The sister group relationship of the korethrasterid genera Remaster and Peribolaster to pterasterids is also well supported by molecular evidence (Mah and Foltz 2011a fig. 1).

Tremasterines, korethrasterids and pterasterids are united by an extensive suite of morphological characters which most importantly include a unique, plate-floored interradial channel which extends from the abactinal side of the disc, adjacent to the primary interradials, to the oral ossicles. This is used to brood young in some taxa, and is unknown in any other asteroids. The relationships are further supported by detailed homologies of 
many ossicle types between the taxa (Gale 2012). The evolutionary transition between the families is demonstrated by Jurassic fossils described here, in combination with extant taxa.

\section{Phylogeny}

A set of 63 characters (Appendix 1) and 11 taxa, including Astropecten irregularis as an outgroup, generated a character matrix (Table 1). This was analysed with Mesquite, using implicit enumeration, and produced a single most parsimonious tree, with a length of 80 steps (Fig. 18). The tree has the form of a ladder, extending successively from Asterina gibbosa (at the base), to Tremaster mirabilis, then crownwards through korethrasterids to pterasterids. Bootstrap support values are good, with a mean value of 87.2 . Whilst the pterasterids are a monophyletic group with a bootstrap support of 87 , the korethrasterids form a paraphyletic stem group.

When the cladogram, with the distribution of living and fossil taxa, is plotted against stratigraphy (Fig. 19), it is evident 1) that the velatid clade was already present by the earliest Jurassic, and 2) that the pterasterids had evolved by the Middle Jurassic. However, a number of extant groups have no fossil record and therefore display very long ghost ranges (A. gibbosa, K. hispidus and R. gourdoni). This pattern of Early Jurassic (or even Triassic) radiation is similar to that displayed by many neoasteroids (e.g., Gale 2011a, fig. 27). The fossil record of Triassic asteroids includes very few taxa, if any, that can be referred confidently to extant groups (Gale 2011a), and it is possibie that the radiation took place very rapidly in the earliest Jurassic. 


\section{Localities}

A large part of the fossil asteroid material described in the present paper was obtained by bulk sampling and washing of fossiliferous Jurassic clays collected at various localities in Belgium, France and Germany. These are as follows:

1. Fontenoille, province of Luxembourg, Belgium. Old quarry, now overgrown; middle Hettangian, Alsaites liasicus Zone, Marnes de Jamoigne Formation, bed C2 (for details, see Delsate et al. 2002).

2. Sedan, Ardennes, France. Construction site for lorry park adjacent to dual carriageway N43. Most material was obtained from the 2-4 m level; Pliensbachian, Prodactylioceras davoei Zone (for details, see Thuy et al. 2011).

3. Longwy, Ardennes, France. Road cutting on N52; lower Bajocian, Laeviuscula Zone (see Delsate 1993; Thuy 2015). Samples from the lower of two marl beds assigned by Delsate to the Longwy Formation, as "Marnes bleu-gris et band calcaire lumachelliques".

4. Andelot-Morval, $6 \mathrm{~km}$ east of Saint-Amour, Départment du Jura, France. Section adjacent to fishing lakes, $800 \mathrm{~m}$ NNW of Andelot-Morval (Fig. 20), co-ordinates: 46.26.01.24N, 5.25.31.81E; lower Oxfordian, Marnes à C. renggeri, praecodatum to bukowskii subzones (see Jardat 2010).

5. Savigna, Départment du Jura, France ; upper Oxfordian, Stenocycloides Subzone, bifurcatus Zone (for details, see Gale 2011b).

6. Plettenberg Kalkbruch, near Dotternhausen, southern Germany; upper Oxfordian, bimammatum Zone (see Olivier et al. 2004). 


\section{Systematic palaeontology}

Neoasteroidea Gale, 1987

Spinulosida Perrier, 1884

Remarks. The Spinulosida, as defined by Gale (2011a, text-fig. 20) incorporates the families Asterinidae and Solasteridae, plus the Velatida. The close relationship of the Asterinidae and Solasteridae has also been demonstrated from molecular data (Matsubara et al. 2004; Janies et al. 2011; Mah and Foltz 2011b). The Spinulosida evidently split into two clades early in their history; one includes the extinct Plumasteridae (Gale 2011b) and the Jurassic to present-day Solasteridae. The other clade includes the Asterinidae and Jurassic Tropidasteridae. Evidently this gave rise to the velatid clade (see above, and Fig. 18). This last relationship is in conflict with molecular phylogenies (e.g., Feuda and Smith 2015).

Chevronida nov.

Diagnosis. Spinulosida in which plate-roofed interradial channels extend from the distal surface of the primary interradial ossicles to the proximal surface of the odontophore. Stratigraphical range: Hettangian to Recent.

Remarks. The Chevronida nov. comprise Tremasteridae, plus all the Velatida. 
Diagnosis. Abactinally domed Chevronida nov. in which the adambulacrals are broad and short and the large actinal interareas are constructed of numerous rows of small actinal ossicles, each running from the adradial margin of the adambulacral to the margin.

Remarks. The Tremasterinae is here elevated to family level, and includes Tremaster and Mesotremaster, which appear to be closely related. Protremaster is more derived and is placed in the basal Korethrasteridae (see below). The basic skeletal construction is closely similar between Tremaster and Mesotremaster (compare Fig. 6A-D with 6F; pl. 2 of Hess 1987), but it appears that in M. zbindeni the "chimney" of ossicles forming the actinal portion of the interradial duct in T. mirabilis (see Fig. 6C, left-hand side) has been lost, and that part of the duct is open actinally (Figs $4 \mathrm{~K}, 6 \mathrm{~F}$ ). Tremasterids are known from the Bajocian to the present day, but probably originated in the Triassic (Fig. 19).

Velatida Perrier, 1884

Diagnosis. Chevronids nov. in which the actinal surface is constructed entirely from adambulacrals, which extend from the ambulacral grooves to the ambitus (Fig. 7); actinal ossicles are absent.

Korethrasteridae Danielssen and Koren, 1884

Diagnosis. Velatids in which the adambulacrals broaden distally from articulation with the oral to the $3^{\text {rd }}$ or $4^{\text {th }}$ ossicle (Fig. $5 \mathrm{G}-1$ ), and possess an elongated adambulacral extension. The chevron-floored interradial grooves are open on the actinal surface. 
Remarks. Korethrasterids are technically paraphyletic, as they do not include all the descendant taxa (Pterasteridae), but the term provides a useful handle for stem group pterasterids. The group has a long history, dating back to the Hettangian, but suffers from a rather poor fossil record. Undescribed forms of a genus that is close to Peribolaster are present in Cenomanian and Campanian chalks of the Anglo-Paris Basin (Fig. 19).

Protremaster Smith and Tranter, 1985

Diagnosis. Korethrasterids with short arms and broad interradii, in which the interradial ducts are closed abactinally but open actinally (Figs $4 \mathrm{~L}, 6 \mathrm{E})$. The abactinal surface is composed of small, robust imbricating ossicles set in diagonal rows.

Remarks. Protremaster is known from a single specimen from the Sinemurian (Lower Jurassic) of Alexander Island, Arctic Peninsula, BAS (British Antarctic Survey) KG 2986.17 (Fig. 6E). This is an external mould of a folded individual which provides excellent morphological detail of both actinal and abactinal surfaces.

Thuyaster gen. nov.

Diagnosis. Korethrasterid in which the arms are narrow, and the actinal surface is constructed from crescentic adambulacrals, which possess a short, arrowhead-shaped adambulacral extension bearing two spine attachment sites. The abactinal ossicles are oval to trapezoidal in outline and possess a central region constructed of coarsely perforate stereom and a margin of finer stereom.

Type species. Thuyaster fontenoillensis sp. nov. 
Derivation of name. In honour of the work of Dr Ben Thuy (Luxembourg, Luxemburg) on fossil and living ophiuroids, who drew my attention to the site of Fontenoille which yielded the type material of the type species.

Remarks. Thuyaster gen. nov. differs from the other two basal korethrasterids, Protremaster and Korethraster, in the distinctive morphology of the adambulacral ossicles. It also differs from Korethraster in the absence of a tuft of spines (fascicle) on the abactinal plates.

Thuyaster fontenoillensis sp. nov.

Fig. 14A-H, L, N-T

Diagnosis. As for genus.

Material. Over 150 ossicles, including abactinals, ambulacrals, adambulacrals, a single chevron plate, and orals, from the middle Hettangian (Alsaites liasicus Zone), Fontenoille, southeast Belgium, bed C2 of Delsate et al. (2002).

Types. The adambulacral figured (Fig. 14C, D) is the holotype. NHMUK EE 16954. The other illustrated ossicles (Fig. 14A, B, E-G, L, N, O-T) are paratypes (NHMUK EE 16593, 16595-16606).

Description. Adambulacral ossicles (Fig. 14A-F, L) are morphologically highly distinctive, and it is possible to place proximal plates in their correct relative positions (Fig. 5G). The plate adjacent to the oral (adamb 1; see Fig. 14A, B) is proportionately narrow and is 
strongly imbricated by adamb 2 . The actinal surface is gently curved and bears four spine pits. Adamb 3 is broad and short (Fig. 14C, D) and the short adambulacral extension is arrowhead shaped. The actinal surface bears four spine pits of which the lateral one is largest. Immediately distal adambulacrals are strongly crescentic and possess a distal spur at the base of the triangular adambulacral extension (Fig. 14F). The extension carries two elongated spine pits. The ambulacrals (Fig. 14G, H) have strongly waisted shafts, and enlarged proximal flanges on the ambulacral heads (compare Gale 2011a, text-fig. 9), but evidently lack distal flanges. The one poorly preserved chevron ossicle (Fig. 14N) has a well-developed proximal process. Several well-preserved oral ossicles are present in the material (Fig. 14Q,R); the body of the oral is square and the apophyse is slightly oblique. Two rounded bosses for large suboral spines are present on each plate, and three oral spine bases are present on the proximal margin of the body. The abactinal ossicles (Fig. $140, P, S, T)$ are flattened, with a thicker central portion and thinner margins, and have irregular oval to trapezoidal outlines. They imbricated strongly, and the abactinally positioned (originally external) portions of the plates are made up of coarser perforate stereo than the more actinal flanges which were covered by the adjacent plate.

Remarks. Although known only from disassociated ossicles, it is possible to provide a partial reconstruction of the overall morphology of $T$. fontenoillensis gen. nov., sp. nov. (Fig. 5G). The adambulacrals were relatively narrow in comparison to those of Protremaster or Korethraster, indicating that the arms were also narrow. The abactinal surface consisted of strongly imbricating small plates, similar to those of Korethraster hispidus (Fig. 14M), but these evidently lacked spines completely, rather like those in Mesotremaster zbindeni (Hess 1981, pl. 2).

Becuaster gen. nov. 
Diagnosis. A korethrasterid in which the J- shaped adambulacrals bear three rounded adradial spine pits, and three elongated abradial pits.

Derivation of name. After Becu, the region of Andelot-Morval which yielded the type material.

Type species. B. fusiliformis sp. nov.

Remarks. The adambulacrals of Becuaster gen. nov. differ significantly from those of other korethrasterid genera in the distinctive distribution of the spine bases on the adambulacral extension (see below).

Becuaster fusiliformis sp. nov.

Figs $12 \mathrm{C}, \mathrm{D}, 17 \mathrm{H}, \mathrm{I}, \mathrm{M}$

Diagnosis. As for genus.

Material. Ten adambulacral ossicles and five probable abactinal ossicles from the lower Oxfordian Marnes à C. renggeri, praecordatum to bukowskii subzones at Andelot-Morval, 6 km east of Saint-Amour, Départment du Jura, France. Samples And1-5, And 9, And 10; common only in And 9.

Types. The adambulacral figured here (Figs 12C, D) is the holotype, NHMUK EE 16587. The other figured adambulacrals (Fig. 17H, I, M) are paratypes. 17H, NHMUK EE 16635; 17I, NHMUK EE 16636; 17M, NHMUK EE 16639. 
Derivation of name. After the pistol-like appearance of the adambulacrals, hence fusil, pistol, and formis, in the shape of.

Description. The adambulacrals (Figs 12C, D, 17H, I, M) are asymmetrically crescentic, Jshaped and three to five times taller than wide. The adradial part of the ossicle is angled to the axis, slightly curved, and carries four large, prominent, horseshoe-shaped spine bases. The adambulacral extension is of variable width, and bears two further spine bases, which are bifid and elongated. The most abradial spine base bore the large actinolateral spine. A rounded adambulacral extension articulation (adma, see Fig. 1G) is present on the more proximal ossicles (e.g., Fig. 17H, M). In the most proximal adambulacrals (Figs 12C, D, $17 \mathrm{H}, \mathrm{M}$ ) the adambulacral extension is shorter; in more distal ones it is longer (Fig. 17I). The inner (abactinal) surface of the adambulacrals is flat (Fig. 12D), and the facet for insertion of the adadm muscle is well developed (compare with Gale 2011a, pl. 9, fig. 10, for Remaster gourdoni; compare also Fig. 12F for Peribolaster lictor). A possible radial abactinal is also illustrated here (Fig. 8F); this is four lobed, with a low central prominence constructed of ribs of stereom. The proximal two processes are shorter and blunter.

Remarks. Becuaster fusiliformis gen. nov., sp. nov. is probably closest to Peribolaster in overall adambulacral morphology, in the crescentic form of the ossicle (compare Fig. 12CF). However, it differs in the raised spine bases, and the presence of a spine base halfway along the adambulacral extension. The possible abactinals (Fig. 8F) are also similar to those of Peribolaster (Fig. 15G).

Pterasteridae Perrier, 1875 
Diagnosis. Velatida in which the primary radial ossicles carry a vase-shaped pedicel. Muscles are present between abactinals and abactinal-chevron ossicle contacts.

Included genera. Savignaster Gale, 2011, Longwyaster gen. nov., Propteraster gen. nov., Hansaster gen. nov., Pteraster, Benthaster, Calyptreaster, Diplopteraster, Hymenaster, Hymenasteroides and Euretaster.

Remarks. Definition of the family is based upon arbitrary criteria, because the transition between korethrasterids and pterasterids is gradual and represented by the progressive acquisition of characters (Figs 18, 19). However, the presence of muscularised abactinal ossicles and enlarged primary radials, presumably supporting an osculum, is an indication that the respiratory mechanism characteristic of extant pterasterids (Nance and Braithwaite1981) was at least in part functioning in fossil forms.

Longwyaster gen. nov.

Diagnosis. A basal pterasterid, which displays weak muscularisation of the abactinal ossicles, and in which the primary radial ossicle bears a low, broad pedicel.

Type species. Longwyaster delsatei sp. nov.

Remarks. Longwyaster gen. nov., from the lower Bajocian, is the oldest known pterasterid. Only the primary radial and a few other abactinal ossicles bear pedicels; the radial ossicles and most abactinals possess a raised area carrying a ring of spine bases and are similar to abactinals in Peribolaster. 
Longwyaster delsatei sp. nov.

Fig. 16A-S

Diagnosis. As for genus.

Origin of name. For Dominique Delsate, who discovered and described the type locality.

Material. Over 75 ossicles, including adambulacrals, ambulacrals, orals, abactinals, chevron ossicles and actinolateral spines from a road cutting on the N52 near Longway (Ardennes, France); lower Bajocian (Laeviuscula Zone; Delsate 1993; Thuy 2015).

Samples were recovered from the lower of two marl beds described by Delsate (1993) and referred to the Longwy Formation.

Types. The figured adambulacral ossicle (Fig. 160) is holotype, NHMUK EE16628. The other figured ossicles (Fig. 16A-N, P-S) are paratypes, NHMUK EE 16617-16627, 1662932.

Description. The adambulacrals (Fig. 160-Q) are flat, and the adambulacral extension is set at an angle of about $120^{\circ}$ to the body of the ossicle. The body of the ossicle bears two to three spine bases, and a further elongated spine attachment is present on the abradial end of the extension. The ambulacrals (Fig. 16R, S) have an enlarged, triangular proximal head, and a small, broken distal flange. The area of articulation with the adambulacrals is divided into a flat actinal region separated from the abactinal part by a concave surface. The oral ossicles (Fig. 16K, L) are poorly preserved, but show a square oral body, bearing one or two suboral spine attachment surfaces, and a tall, vertical apophyse. The abactinal ossicles show diverse morphologies. The primary radial ossicles (Fig. 16G, H) have well- 
developed lateral processes, and a single, broad distal process. The pedicel is low, robust, and expands slightly abactinally; the abactinal surface is concave.

The radial ossicles of the arm (Fig. 16B, J) are symmetrical and bear four processes, of which the proximal pair are shorter. The abactinal surfaces of the tips of the radials are concave and constructed of fine stereom, suggestive of some muscularisation. The radials possess a proximally situated low swelling which bears a crown of small bosses for spine articulation. Abradially positioned abactinal plates are asymmetrical (e.g., Fig. 16A, C, D, M) and also have a swollen central region with spine attachment bosses. The chevron plates (Fig. 16E, I) are Y-shaped, and the actinal surfaces close to the interradius are constructed of fine stereom, suggestive of muscle attachment. Unfortunately, the radially directed processes, which contact the abactinals, are insufficiently well preserved to permit the identification of muscle insertion sites. A single actinolateral spine was found (Fig. 16N), which expands distally, and bears longitudinal rows of perforations. This spine is very similar to those seen on the holotype of Savignaster wardi (see Gale 2011a, pl. 21, figs 1, 2, 5).

Remarks. Longwyaster delsatei gen. nov., sp. nov. shares similarities with Savignaster wardi, notably the morphology of the primary radial ossicles, in which the pedicel is relatively low and broad (compare Fig. 13A, D with Fig. $16 \mathrm{G}, \mathrm{H}$ ), but it has a short spur in S. wardi. The chevron plates are also similar in their overall construction (compare Fig. 13K, L with Fig. 16E, I), as are the adambulacrals, adambulacrals and the actinolateral spines. The genera differ most importantly in the morphology of the abactinals, which in $S$. wardi all bear a vase-shaped pedicel (Fig. 13G, I, J), similar to those present in some extant pterasterids. The abactinals of $L$. desatei gen. nov., sp. nov., bear a low, rounded protuberance, of variable height (compare Fig. 16A, D with Fig.16C, F, M), which carries a 
ring of spine bases on the top; these are rather similar to abactinals in the korethrasterid Peribolaster (Fig. 15G).

Savignaster Gale, 2011a

Diagnosis. Pterasteridae in which the radials abactinals are trapezoidal and bear a short, abactinally expanding pedicel; primary radial ossicle carries a short proximal spur.

Type species. S. wardi Gale, 2011a, by subsequent designation herein.

Savignaster wardi Gale, 2011a

Fig. 13A-R

2011a Savignaster wardi Gale, p. 88, pl. 21, figs 1, 2, 5; pl. 22, figs 1-3; pl. 23, figs 38, 11,12; pl. 24, figs 4-8, 10-12, 14-16.

2011b Savignaster wardi Gale; Gale, p.82 fig. 12a-i.

Diagnosis. As for genus.

Types. The articulated individual figured by Gale (2011a, pl. 21, figs1, 2, 5; pl. 22, figs 1-3) is the holotype, NHMUK EE 13610. Paratypes include isolated ossicles (NHMUK EE 13611-13632), all from the upper Oxfordian bifurcatus Zone of Savigna, Jura, France.

Remarks. There is little to add to the detailed description of Gale (2011a). More material of this species has since been obtained from Savigna, including, importantly, a primary radial ossicle (Fig. 13A-D; NHMUK EE 16589). This has a short, abactinally expanding pedicel 
with a flat upper surface, surrounded by spine attachment scars, and a short proximal spur, into which muscles depressing the crown of spines must have inserted. The structure is therefore broadly similar to that of pterasterids which possessed a powerfully functioning osculum (compare with Fig. 9). However, the primary radial is only weakly muscularised, and an osculum therefore was weakly developed, if present at all. Gale (2011a) argued that the presence of large, broad actinolateral spines in S. wardi, similar to those in Remaster, precluded the possibility that a canopy was present.

Hansaster gen. nov.

Diagnosis. Pterasteridae in which the adambulacrals possess an elongated extension, and in which the base for the apertural spine is widely separated from those supporting the adambulacral spine membrane. The primary radials bear a proximally sloping face for spine articulation and a prominent proximal spur.

Type species. Hansaster trimbachensis (Gale, 2011a).

Derivation of name. In honour of the late Hans Hess of Basel.

Remarks. In many respects, $H$. trimbachensis is remarkably similar to extant species of Pteraster, in the overall development of the abactinal ossicles, ambulacrals, chevron ossicles and the mouth frame (see Figs 8-10). However, the primary radial ossicles (Fig. 9A, B, F-J) display a number of important differences from those of extant Pteraster, most notably in the possession of a large, triangular, proximally sloping surface for attachment of 
spines supporting the osculum, and a prominent spur on the proximal margin, for insertion of the muscles depressing these spines. In all extant Pteraster examined ( $>10$ species) the spines attach to the narrow, crescentic, flattened summit of the primary radials, and the depressor muscles insert into a cavity on the proximal surface of the pedicel (Fig. 9M, N). Differences in the adambulacrals are also significant.

Hansaster trimbachensis (Gale, 2011a)

Figs. 8A-C, E-L, O, 9A, B, F-H, 10C-E, I, J, M, O, P, Q, S, T, 12A, B, G, H, 17A-E 2011a Savignaster trimbachensis Gale, p. 92, pl. 23, figs 1, 2.

Types. The large adambulacral figured by Gale (2011a, pl. 23, figs 1, 2) is the holotype, NMB M 11143, from the upper Oxfordian at Rumperl, southwest of Trimbach, near Olten, Canton Solothurn, Switzerland.

Material. The species is abundant at Andelot-Morval in the basal Couches de Passage (bukowskii Zone), the level of sample And 5 (18-19 m; Fig. 20A). This material includes 15 orals, 3 circumorals, a single odontophore, 15 adambulacrals, 10 ambulacrals, 2 primary interradials, 4 primary radials, 22 abactinals and 3 interradial chevron ossicles. From Trimbach comes a single specimen each of an adambulacral and ambulacral, and from the Plettenberg near Dotternhausen, southern Germany, there is one adambulacral.

Description. Adambulacrals (Figs 12A, B, G, H, 17A-E) are J-shaped and the long adambulacral extension is angled to the body of the ossicle. The ossicles are flattened and imbricated strongly. Two to three crater-shaped spine bases, arranged in an arc, are set on the adradial margin of the plates; these bore similar spines supporting an adambulacral membrane (Fig. 1H). An elongated spine base, set on the proximal margin of the ossicle, 
and separated from the adradial arc, probably carried the apertural spine (Fig. 1H). A short distal process on the base of the extension (e.g., Fig. 17A, B) carries the adamb extension muscle (adexm). The adjacent adamb extension articulation (adexa) is variable in size and shape (compare Fig. 12A, G). The elongated adamb extension carried a large actinolateral spine on the abradial margin, onto which a muscle inserted.

The ambulacrals (Fig. 8B, C, I) have waisted shafts and strongly asymmetrical heads. The proximal flange is enlarged and triangular, and a short distal flange is present. The ambulacral base expands abradially, and a concave region for articulation with the adambulacral us present. The dentition is concentrated on a central process. The chevron ossicles (Fig. 10M, O, Q, T) are broken but compare well with those found in Pteraster (Fig. 10N, R). Plates with an abactinal position have elongated interradial processes (Fig. $10 \mathrm{M}, \mathrm{Q})$ and thin lateral processes to contact abactinals. Chevrons with a lateral position have shorter lateral processes (Fig. 10T). Finally, plates positioned actinally, adjacent to the odontophore (Fig. 100) have a single lateral process. Plates from the mouth frame include oral ossicles (Fig. 10I, J), which possess a trapezoidal body and an obliquely inclined apophyse. The oral body bears a rounded attachment site for a single, large, suboral spine, and the proximal margin carries a row of five closely spaced bases for oral spines. The circumoral ossicles (Fig. 8J, K) have an elongated, vertically orientated distal process, and a very short proximal process. The body of the ossicle is robust. A single odontophore was recovered (Fig. 10C-E), which is rectangular in actinal/abactinal view (Fig. 10C, D) with two wing-like lateral processes, which on the actinal surface (Fig. 10D) acted as attachment sites for the oral-odontophore muscles. The distal end (Fig. 10C) had an articulation structure which contacts the most proximal chevron ossicle.

The primary radials from Andelot-Morval are remarkably well preserved (Fig. 9A, B, $\mathrm{F}-\mathrm{H})$, and have a four lobed basal structure (bp), and a tall, abactinally expanding pedicel column (co), divided into a shaft and head. The distal surface of the pedicel bears weak 
ridges and grooves, and is weakly convex. The proximal surface is triangular, and slopes down towards a proximal spur; it bears irregular grooves and ridges (Fig. 9B, H) which must have supported an array of spines. The spur forms a blunt projection near the base of the proximal surface (Fig. 9G), onto which the muscle fibres depressing the spines inserted. The other abactinal ossicles (Fig. 8A, E, G, H, L, O) are delicately constructed and carried very tall, narrow pedicels (Fig. 8G, H). The radial ossicles (Fig. 8L) are four lobed and symmetrical, with elongated proximal processes and shorter distal ones. The abradial abactinals are less symmetrical (Fig. 8A, G, O). The articulating basal processes of abactinals bear facets for insertion of interabactinal muscles (e.g., Fig 8L, bottom right).

Remarks. In many ways, Hansaster trimbachensis closely resembles a living species of Pteraster; the abactinals have a similarly delicate construction with large spaces between for papulae, and the tall pedicels must have supported a canopy (compare abactinals in Fig. 8). Similarly, the chevron ossicles and mouth frame ossicles are nearly identical. However, two significant differences exist. Firstly, and importantly, the primary radial ossicles appear similar between Pteraster and Hansaster gen. nov. in distal view (Fig. 9A, $\mathrm{F}, \mathrm{K})$, but the proximal surfaces and muscle insertion sites are very different. In Pteraster corynetes (Fig. 9L, M) and P. temnochiton (Fig. 9N) the spines surrounding the osculum are restricted to the crest of the ossicle, and the muscles depressing these spines run down and insert into a cavity on the spur. In Hansaster gen. nov. (and Propteraster gen. nov., see below) the oscular spines were attached across a large triangular surface which sloped proximally (Fig. 9B, G, H), and the muscles depressing these must have attached to the outside of the spur beneath. Secondly, there are minor differences in the morphology of the adambulacrals. The group of spine bases which probably supported the adambulacral spine membrane (see Fig. $1 \mathrm{H}$ ) can be identified in H. trimbachensis (e.g., Fig. 12G). The spine base of the apertural spine can also be identified, but it is in a slightly 
different position to that in living pterasterids, in which it is closer to the adambulacral extension (Fig. 12M, N). A well-developed adamb extension articulation (adexa) is present in both Hansaster gen. nov. (Fig. 12G) and Pteraster (Fig. 12M, N), but the adamb extension muscle (adexm) appears to be smaller in the Jurassic forms. However, this may be a matter of preservation, as the muscle is set on a thin, fragile flange.

Propteraster gen. nov.

Diagnosis. Pterasterids characterised by very tall, slender vase-shaped primary radials, which possess an elongated waist. Adambulacrals with short adex, flattened form, and apertural spine positioned on proximal margin of ossicle.

Type species. P. amourensis sp. nov.

Remarks. Propteraster gen. nov. differs from existing pterasterids in the tall form of the primary radial ossicles and the position of the apertural spine on the adambulacrals. From Hansaster gen. nov. it differs in the short adambulacral extension and the well-developed row of spine bases on the proximal, adradial margin.

Propteraster amourensis sp. nov.

Figs 9C-E, I, J, R, 10A, B,12I, J, 17F, G, J-L

Material. Five adambulacral ossicles, three orals and five primary radial ossicles from samples And 7-10, Marnes à C. renggeri, C. praecordatum Zone, Andelot-Morval (Fig. 20A). The orals and primary radials are associated with the adambulacrals and all are thought to belong to the same taxon. 
Types. The well-preserved adambulacral (Fig. 12 I,J; Fig 17F,G) is the holotype, NHMUK 16588, from sample And 7. The other figured adambulacral ossicles are paratypes; Fig. 17J,K NHMUK EE 16637. Fig. 17L, NHMUK EE 16638.

Derivation of name. After Saint-Amour, the neighbouring town to Andelot-Morval (Fig. 20B).

Description. The adambulacrals (Figs 12I, J, 17F, G, J-L) are obliquely flattened and have a long, gently curved proximal margin and a short adambulacral extension. The adradial proximal margin bears three to five, closely spaced, rounded spine pits, set on a slightly raised ridge; these presumably carried the adambulacral spine membrane (see Fig. $1 \mathrm{H}$ ). The most abradial spine pit on the proximal margin is separated from the others and has a different orientation (Fig. 17J), as it is directed abradially. This carried the apertural spine (see Fig. $1 \mathrm{H}$ ). The adambulacral extension is short, and carried a single actinolateral spine at its abradial extremity. A well-developed adexa surface is present, and a very narrow strip of stereom on the distal border of the ossicle (Fig. 17J) provided an insertion site for the adexm.

The oral ossicles associated with the adambulacrals (Fig. 10A, B) have a highly distinctive morphology. The oral body is rhombic, the apophyse tall and vertically orientated. Two suboral spine attachment sites, of different sizes, are present. On the proximal margin, five small attachment sites for oral spines are present.

The primary radial ossicles associated with the adambulacrals (Fig. 9C-E, I, J, R) are tall (up to five times taller than the maximum width), slender, waisted and vase shaped. The basal portion is only preserved on one specimen (Fig. 9C-E) and the processes are broken away. The proximal surface of this specimen (Fig. 9E) carries a 
spur, which is asymmetrical and displaced to one side. The abactinal surface is triangular and slopes proximally; it has ridges and grooves for spine articulation. The other specimens (Fig. 9I, J, R) are broken abactinal fragments of very tall, strongly waisted primary radials.

Remarks. The adambulacral ossicles are remarkably similar to those of some living species of Pteraster (compare Fig. 12I and M) in their shape, possession of a row of spines to support the membrane on the proximal, adradial margin, the short adamb extension and the very flattened form of the ossicles. They differ in the position of the apertural spine, which in living Pteraster is set close to the base of the adamb extension (Figs $11 \mathrm{~J}, 12 \mathrm{M}, \mathrm{N}$ ), but in $P$. amourensis gen. nov., sp. nov. is positioned on the proximal margin (Fig. 17F, J, L). They differ also in the relative development of the flange which bears the adex muscle. In living Pteraster (Fig. 12M, N) this is prominent and relatively large, but it appears as a very narrow strip in P.amourensis (e.g., Fig 17J). As in Hansaster gen. nov., this may simply be a preservational difference. The primary radials, however, differ considerably from those of any of the twenty or so living pterasterids which I have examined, in their very tall pedicels.

Pterasteridae? indet.

Fig. 15A-F, H-L

Material. 25 ossicles, including chevron plates, ambulacrals, abactinals, circumorals and orals from a construction site for a lorry park adjacent to dual carriageway N43, Sedan, Ardennes. Most material was obtained from the 2-4 m level; Pliensbachian, Prodactylioceras davoei Zone (for details, see Thuy et al. 2011). 
Description. The Sedan site yields abundant asteroids of the families Plumasteridae and Tropidasteridae (Thuy et al. 2011), both articulated fragments and loose ossicles. Less common are forcipulatid asteroid ossicles, and a range of ossicles which originate in velatid starfish. However, the absence of the important adambulacrals and primary radial ossicles makes these hard to place taxonomically. They include chevron ossicles (Fig. 15A-E), which are well differentiated into more symmetrical, abactinally positioned forms (Fig. 15A-C) and asymmetrical, more actinal ones (Fig. 15D, E). The terminal depressions on the lateral processes of some chevrons which contacted abactinal ossicles (Fig. 15AC; compare with Fig. 4F) is suggestive of the presence of muscles linking these with the abactinal ossicles, as in Longwyaster gen. nov. (Fig. 16E, I) and Savignaster (Fig. 13K, L). The single four-lobed abactinal radial ossicle (Fig. 15F) which has a low, central boss, is similar to those of Longwyaster gen. nov. (compare with Fig. 16B, J). The delicately constructed single circumoral ossicle (Fig. 15K) is comparable with circumorals attributable to Hansaster gen. nov.(compare with Fig. 8K). However suggestive these comparisons are, none of the ossicles are entirely diagnostic of the Pterasteridae, so their affinities will remain uncertain, at least for the time being.

\section{Functional evolution}

Abactinal and adambulacral evlution. Asterinids are mostly specialist hard-substrate dwellers (Clarke and Downey 1992) which live on rocky outcrops using suckered tubefeet and feed on surface films using stomach eversion. The morphology of forms such as Asterina and Tremaster, which possess short arms, large actinal interareas and a skeleton of imbricating, tile-like abactinal and actinal ossicles, are well adapted to life on hard substrates and Protremaster may well have inhabited such. 
The velatid lineage (Fig. 18) is marked by progressive reduction of the abactinal skeleton. The initial drive for this is likely to have been the need for increased oxygen, initially by the enlargement of the papulae and concomitant reduction of the abactinal skeleton (Peribolaster and pterasterids). The initial development of a pumping mechanism is represented by the evolution of inter-abactinal muscles. These contract to decrease the coelomic volume, causing the papulae to balloon and increase the surface area available for oxygen uptake (Nance and Braithwaite 1981). The pedicels afford an attachment site for the papulae, increasing their efficiency by raising them higher above the body surface. The progressive increase in the size of inter-abactinal muscle insertion sites is evidence of the progressive importance of this pumping mechanism.

The next transition was the development of a muscular canopy linking the pedicel spines, fused to a membrane linking the actinolateral spines. This was accompanied by formation of apertures between the adambulacrals and apertural spines which opened and closed these, plus formation of an osculum through which to expel water. All of these adaptations are essential for the complex respiratory mechanism to function (Figs $1 \mathrm{H}, 2)$. Several of these features can be identified from ossicle morphology:

1) the presence of a fully functioning osculum is indicated by the morphology of the primary radial ossicles (Fig. 9). In many extant pterasterids (e.g., Fig. 9K-M) the pr has a tall column and a broad head to support the numerous spines which open and close the osculum. The muscles which depress these spines (during inflation phase, see Fig. 2) insert into a cavity on the proximal spur of the pr.

2) The presence of a specialised apertural spine, essential to open and close the apertures between adambulacrals during deflation (Fig. 2). The apertural spine attachment (aps) in P. tesselatus (Fig. 11J), P. corynetes (Fig. 12M) and $P$. temnochiton (Fig. $12 \mathrm{~N}$ ) is separated from and lateral to the bases of the 
adambulacral spines supporting the adambulacral spine membrane (ads - see Fig. $1 \mathrm{H})$.

The primary radials of Hansaster gen. nov. trimbachensis and Propteraster amourensis gen. nov., sp. nov. (Fig. 9A, B and C-E) possess a proximally sloping surface on their heads, on which numerous spine bases are visible, and a well-developed proximal spur onto which the depressor muscles must have inserted. They therefore possessed a functioning osculum. The adambulacrals (Figs 12G, I, 17F, J) of these species show a spine base lateral to and separated from those of the other adambulacral spines (best seen in Fig. 17J), which can be interpreted as an apertural spine attachment site. It therefore seems probable that Hansaster gen. nov. and Propteraster gen. nov. were adapted for the complex respiratory cycle described in Pteraster tesselatus.

In the basal pterasterids Longwyaster gen. nov. (Fig. 16D, G) and Savignaster (Fig.13A-D) the primary radial ossicles have broad, flat-topped heads which clearly bore a crown of spines (Fig. 13A). In Savignaster, a short proximal spur, high upon the column, is present (Fig. 13B), into which muscles from the proximal crown of spines presumably inserted. If this did function as an osculum, it certainly could not have had a powerful action. Gale (2011a) argued that S. wardi lacked a canopy, because the actinolateral spines were long and broad and resembled those in Remaster (Fig. 7H), which probably functioned as snowshoes.

Respiration, defence and reproduction in the velatid lineage. Work on living pterasterids has led to the suggestion that the canopy has three important functions (Nance and Braithwaite 1979, 1981), in respiration, production of defensive mucus and in creating a brood chamber. In P. tesselatus, copious mucus is generated by cells on the underside of the canopy and those covering the pedicels and abactinal spines and is expelled through 
holes in the canopy called spiraculae. Nance and Braithwaite (1981) argued that pterasterids did not inhabit low oxygen environments, and that all pterasterids generated mucus in a similar fashion, irrespective of whether or not they brooded young beneath the canopy. Therefore, mucus production was likely to be the primary reason why the canopy evolved.

However, the fossil record of pterasterids provides a different perspective, because it is evident that muscularised abactinal and chevron ossicles evolved before the canopy developed. Contractions of the inter-abactinal, abactinal-chevron and inter-chevron muscles in Savignaster would have caused the papulae to balloon on account of coelomic pressure increase, as observed in P. tesselatus (Fig. 2; Nance and Braithwaite 1981) and presumably in other pterasterids. This has the effect of increasing the surface area available for respiratory exchange, and thus enhancing oxygen uptake. Conversely, relaxation of the muscles would cause deflation of the papulae.

Thus, the defensive mucus hypothesis of Nance and Braithwaite (1981) is rejected, and it is argued that the primary selective pressure operating on the common ancestor of pterasterids was to improve oxygen uptake through enlargement and inflation of the abactinal papulae. This ability may have proved very advantageous on the periodically dysoxic Jurassic and Cretaceous sea floors, and possibly aided the family's colonisation of the deep sea. The presence of pterasterid primary radial ossicles with specialisations to support an osculum, and adambulacrals with apertural spines (Propteraster gen. nov., Hansaster gen. nov.) is evidence that the full assembly of structures and mechanisms which would permit secretion of defensive mucus was present by the Oxfordian.

Brooding and vivipary are found widely but very irregularly throughout the Asterinidae (Hart et al. 1997) and the Pterasteridae (Clarke and Downey 1992), and both families are characterised by a great diversity of reproductive styles. Brooding may be found in one genus, a species group or just a single species of a genus. The internal 
calcareous ducts found in Tremaster mirabilis are lined with chevron plates and enable brooding in that species (Jangoux 1982). It is likely that the deep interradial grooves floored by chevron plates described herein in both fossil and extant korethrasterids may have served to brood young, even though these have not been found in situ. Evidence to support this is provided by the fact that the gonopores open directly into these grooves, either abactinally or actinally, in the entire lineage from $T$. mirabilis to the most derived pterasterids.

\section{Conclusions}

Fossil evidence presented here permits velatid asteroids to be traced back to the family Tremasteridae (previously assigned, as a subfamily, to the family Asterinidae), and both are characterised by the possession of interradial ducts floored by calcite plates called chevron ossicles, used to brood young. The clade is therefore called the Chevronida nov. During the Early Jurassic, tremasterids gave rise to the Korethrasteridae, by 1) the evolution of adambulacral extensions, such that the adambulacrals form the entire actinal surface of the asteroid, and 2) the progressive opening of the interradial duct, to form a groove floored by the chevron plates. The korethrasterids have a long geological history, and three genera survive in present-day oceans. Two new korethrasterids are described herein; Thuyaster fontenoillensis gen. nov., sp. nov., from the Hettangian of Belgium, and Becuaster fusiliformis gen. nov., sp. nov. from the Oxfordian of the French Jura. Korethrasterids display a progressive increase in the spaces between the abactinal ossicles, for increased size of the papulae, and the abactinal skeleton became a reticulum of delicate ossicles.

Living pterasterids are highly specialised asteroids, in which the entire abactinal surface of the body is covered by a muscular canopy, supported by abactinal spines. Pterasterids respire, using complex adaptations of the canopy and musculoskeletal system 
to take water into the cavity beneath the canopy, and then expel it through a central opening, the osculum. The interradial grooves are used for brooding, and the interior of the canopy secretes defensive mucus (Nance and Braithwaite 1981). Korethrasterids gave rise to the Pterasteridae, by 1) muscularisation of the abactinal and chevron ossicles, such that contraction reduced the coelomic volume, causing the papulae to inflate, and 2) the development of pedicels on the primary radial ossicles, which supported an array of spines. Two basal pterasterids are described, Longwyaster delsatei gen. nov., sp. nov. from the Bajocian of northern France, and Savignaster wardi Gale, 2011a from the Oxfordian of the French Jura. More derived pterasterids are described on the basis of wellpreserved ossicles from the lower Oxfordian of the French Jura, Propteraster amourensis gen. nov., sp. nov. and Hansaster trimbachensis gen. nov. These both possessed tall, highly specialised primary radial ossicles which indicate the presence of a functional osculum, and adambulacrals very similar to those of living pterasterids. Important features include the presence of apertural spines, which together with the evidence for an osculum, suggest that a canopy was present in these taxa, and that they respired in a fashion similar to the living Pteraster tesselatus. However, there are minor differences from extant pterasterids.

It is concluded from morphological and fossil evidence that pterasterids are not basal neoasteroids as suggested from analysis of molecular data (Janies et al. 2011; Feuda and Smith 2015), but rather evolved from the spinulosan family Asterinidae. Pterasterids do not show any plesiomorphic characters retained from the stem group neoasteroids, nor do they lack crown group synapomorphies. 


\section{Acknowledgements}

This paper is dedicated to the memory of Hans Hess, who did so much excellent research on Mesozoic echinoderms, and described the first known fossil velatids (Jurassic of Switzerland). I wish to thank Hans for showing me his material from Savigna, which included the first Jurassic velatids then known (Gale 2011a, b), and taking me to the site in September 2007. David Ward helped considerably, both in the collection of samples, and by processing the material with his clay machine; Ben Thuy, Keith Holdaway and Sietske Batenburg all assisted with sampling, for which I am very grateful. Ben Thuy showed me both the Sedan and Longwy sections, and Dominique Delsate collected the clay sample from Fontenoille which yielded the material described here. I thank numerous curators of zoological collections for loan of extant species, which has made this study possible, especially Dr Tim O'Hara (Melbourne) for a specimen of Tremaster mirabilis, the Zoological Museum, Copenhagen University, for specimens of Korethraster hispidus and the late Cynthia Ahearne (USNM) for numerous specimens of pterasterids. The SEM work was made possible through the kindness of Christine Hughes, School of Biological Sciences, University of Portsmouth, and is gratefully acknowledged.

Steve Vidovic (University of Portsmouth) provided advice on cladistics, and analysed the data matrix. I am grateful to two reviewers, John Jagt and an anonymous reviewer, for most thoughtful and useful reports. 


\section{References}

Alton, M.S. (1966). A new sea-star from the northeastern Pacific Ocean, Asthenactis fisheri n. sp., with a review of the family Myxasteridae. Deep Sea Research, 13, 687-697.

Blake, D. B. (1987). A classification and phylogeny of post-Palaeozoic sea stars (Asteroidea: Echinodermata). Journal of Natural History, 21, 481-528.

Blake, D.B. (1988). Paxillosidans are not primitive asteroids: a hypothesis based on functional considerations. In: Burke, R.D., Mladenov, P.V., Lambert, P. and Parsley, R.L. (eds). Echinoderm biology: Proceedings of the Sixth International Echinoderm Conference, 1988; Victoria, Australia. Pp. 309-314. Rotterdam: A. A. Balkema.

Blake, D.B. (1996). Redescription and reinterpretation of the asteroid species Tropidaster pectinatus from the Jurassic of England. Palaeontology, 39, 179-188.

Chia, F.-S. (1966). Development of a deep-sea cushion star, Pteraster tesselatus. Proceedings of the California Academy of Sciences 34, 505-510.

Clarke, A. M., \& Downey, M. E. (1992). Starfishes of the Atlantic. Chapman \& Hall, London, 794 pp.

Danielsson, D. C., \& Koren, J. (1884). Asteroidea. Den Norske Nordhavns Expedition, 1876-1878, 11, 1-119. Grøndahl and Sønner, Christiania.

Delsate, D. (1993) Elasmobranches du Bajocien inférieur de Longwy (Meurthe et Moselle). Cossmanniana, hors série, 2, 56-58.

Delsate, D., Duffin, C. J., \& Weis, R. (2002). A new microvertebrate fauna from the Middle Hettangian (Early Jurassic) of Fontenoille (Province of Luxembourg, South Belgium). Memoirs of the Geological Survey of Belgium, 48, 1-83.

Downey, M.E. (1970). Marsipaster acicula new species (Echinodermata; Asteroidea), from the Carribean and Gulf of Mexico. Proceedings of the Biological Society of Washington, 83, 309-312.

Fell, H.B. (1958). Deep sea echinoderms of New Zealand. Publications from Victoria University of Wellington, 24, 1-40.

Feuda, R., \& Smith, A.B. (2015). Phylogenetic signal dissection identifies the root of starfishes. PLoS ONE, doi:10.1371/journal.pone.0123331.

Fisher, W.K. (1910). New Pterasteridae from the North Pacific. Annals and Magazine of Natural History. 8(5), 167-170.

Fisher, W. K. (1911). Asteroidea of the North Pacific and adjacent waters, 1. Phanerozonia 
and Spinulosa. Bulletin of the United States National Museum, 76, xiii + $1+$ xiii + $420 \mathrm{pp}$.

Fisher, W.K. (1916). New east Indian starfishes. Proceedings of the Biological Society of Washington, 29, 27-36.

Forbes, E. 1850. Figures and descriptions illustrative of British Organic Remains. Memoirs of the Geological Survey of the United Kingdom, Decade 3, pp. 1-2, pl. 3.

Gale, A. S. (1987). The phylogeny and classification of the Asteroidea (Echinodermata). Zoological Journal of the Linnean Society, 87, 107-132.

Gale, A. S. (2011a). Phylogeny of the Neoasteroidea (post-Palaeozoic Asteroidea, Echinodermata). Special Papers in Palaeontology, 86, 1-112.

Gale, A. S. (2011b). The upper Oxfordian (Jurassic) asteroid fauna of Savigna, Jura, France. Swiss Journal of Palaeontology, 130, 69-89.

Gale, A. S. (2012). Chapter 1. Phylogeny of the Asteroidea. In J. M. Lawrence (Ed.), The Asteroidea, pp. 3-14. Baltimore: Johns Hopkins Press.

Golotsvan, E. V. (1998). New genus and species of starfishes from Pterasteridae (Echinodermata, Asteroidea) family in the Kurilo-Kamchatskii Trench. Zoologicheski Zhurnal. 77(10): 1152-1157.

Griffiths, M. (1978). The biology of the Monotremes. Academic Press, New York, 367 pp.

Hart, M. W., Byrne, M., \& Smith, M. J. (1997). Molecular phylogenetic analysis of life history in asterinid starfish. Evolution, 51, 1848-1861.

Heddle, D. (2012). The descent of the Asteroidea and the reaffirmation of paxillosidan primitiveness. In Emson, R., Smith, A. B. and Campbell, A. (eds). Echinoderm Research, pp179-193. Proceedings of the Fourth European Echinoderms Colloquium, London, UK. A.A. Balkema, Amsterdam, Brookfield-314 pp.

Hess, H. (1972). Eine Echinodermenfauna aus dem mittleren Dogger des Aargauer Juras. Schweizerische Paläontologische Abhandlungen, 92, 1-87.

Hess, H. (1981). Neue Seesternfunde aus dem Dogger des Schweizer Juras. Eclogae geologicae Helvetiae, 80, 907-918.

Ives, J.E. (1888). On two new species of starfishes. Proceedings of the Academy of Natural Sciences of Philadelphia, 40, 421-424.

Jangoux, M. (1982). On Tremaster Verrill, 1879, an odd genus of recent starfish. In J. M. Lawrence (Ed.), International Echinoderm Conference, Tampa Bay. A. A. Balkema, Rotterdam, 155-163.

Janies, D. A., Voight, J.R., \& Daly, M. (2011). Echinoderm phylogeny, including Xyloplax, a progenetic asteroid. Systematic Biology, doi:10.1093/sysbio/syr044. 
Jardat, R. (2010). L'évolution des peuplements d'ammonites au cours de l'Oxfordien inférieur (Zone à Mariae et Zone à Cordatum) de Jura (Est de la France). Carnets de Géologie, article CG2010_A27.

Koehler, R. (1912). Échinodermes nouveaux recueillis dans les mers antarctiques par le ‘Pourquoi Pas?' (Astéries, Ophiures et Échinides). Zoologischer Anzeiger. 39, 151163.

MacBride, E. W. (1921). Echinoderm larvae and their bearing on evolution. Nature,108, 529-530.

Mah, C., \& Foltz, D. (2011a). Molecular phylogeny of the Forcipulatacea (Asteroidea:

Echinodermata): systematics and biogeography. Zoological Journal of the Linnean Society, 162, 646-660.

Mah, C., \& Foltz, D. (2011b). Molecular phylogeny of the Valvatacea (Asteroidea: Echinodermata). Zoological Journal of the Linnean Society, 161, 769-788.

Mah, C., Hamel, J.-F. and Nizinski, M. (2012). Range extensions and Taxonomic notes on Atlantic Myxasteridae (Velatida:Asteroidea). Zootaxa, 3572, 55-72.

McEdward, L.R. (1995). Evolution of pelagic direct development in the starfish Pteraster tesselatus (Asteroidea: Velatida). Biological Journal of the Linnean Society London, $54,299-327$.

Matsubara, M., Komatsu, M., \& Wada, H. (2004). Close relationship between Asterina and Solasteridae supported by both nuclear and mitochondrial gene molecular phylogenies. Zoological Science 21, 785-793.

McClary, D. J., \& Mladenov, P. V. (1990). Brooding biology of the sea star Pteraster militaris (O.F. Müller): energetic and histologic evidence for nutrient translocation to brooded juveniles. Journal of Experimental Marine Biology and Ecology, 142, 183199.

Mortensen, T. (1921). Studies of the development and larval forms of echinoderms. Copenhagen: C.A. Reitzel.

Müller, O. F. (1776). Zoologiae Danicae prodromus: seu Animalium Daniae et Norvegiae indigenarum characteres, nomina, et synonyma imprimis popularium. Hafniae, Typiis Hallageriis. 1-274.

Nance, J. M., \& Braithwaite, L. F. (1979). The function of mucus secretions in the cushion star Pteraster tesselatus Ives. Journal of Experimental Marine Biology and Ecology, 40, 259-266. 
Nance, J. M., \& Braithwaite, L. F. (1981). Respiratory water flow and production of mucus in the cushion star, Pteraster tesselatus Ives (Echinodermata: Asteroidea). Journal of Experimental Marine Biology and Ecology, 50, 21-31.

Olivier, N., Pittet, B., \& Mattioli, E. (2004). Palaeoenvironmental control on spongemicrobialite and contemporaneous deep-shelf marl-limestone deposition (Late Oxfordian, southern Germany). Palaeogeography, Palaeoclimatology, Palaeoecology, 212, 233-263.

Pennant, T. (1777). British Zoology. London 1777. 4th edition (4): 36 and pages 1-154, tab 24, fig 24.

Perrier, E. (1875). Revision de la Stellerides du Muséum d'Histoire Naturelle de Paris. Archives du Zoologie Experimentale et Generale.vol. 4: 265-450.

Perrier, E. (1884). Mémoire sur les étoiles de mer recueilliés dans la mer des Antilles et le golfe du Mexique : durant les expéditions de dragace faites sous la direction de $\mathrm{M}$. Alexandre Agassiz. Archives (Muséum national d'histoire naturelle (France). 2. sér., t. 6.:127-276.

Sladen, W. P. (1889). The Asteroidea. Report of the Scientific Results of the Voyage of the H.M.S. Challenger 1873-1876, Zoology, 30, 935 pp.

Smith, A. B., \& Tranter, T. H. (1985). Protremaster, a new Lower Jurassic genus of asteroid from Antarctica. Geological Magazine, 122, 351-359.

Thomsen, W.C. (1873). The depths of the sea. Macmillan, London. 527 pp.

Thuy, B. (2015). A peri-reefal brittle-star (Echinodermata, Ophiuroidea) assemblage from the Middle Jurassic of the northeast Paris Basin. Ferrantia, 71, 87-106.

Thuy, B., Gale, A. S., \& Reich, M. (2011). An exceptionally preserved echinoderm fauna from the Pliensbachian of Sedan, Ardennes, France. Swiss Journal of Palaeontology, 130, 173-185.

Verrill, A. E. (1879). Notice of recent additions to the marine Invertebrata of the northeastern coast of America, with descriptions of new genera and species and critical remarks on others. Proceedings of the United States National Museum, 2, 165-205.

Villier, L., Blake, D. B., Jagt, J. W. M., \& Kutscher, M. (2004). A preliminary phylogeny of the Pterasteridae (Echinodermata,Asteroidea) and the first fossil record: Late Cretaceous of Belgium and Germany. Paläontologische Zeitschrift, 78, 281-299.

Villier, L., Charbonnier, S. and Riou, B. (2009). Sea stars from Middle Jurassic Lagerstätte of La Voulte-Sur-Rhône (Ardèche, France). Journal of Paleontology, 83, 389-398

Wada, H., Komatsu, M., and Satoh, N. 1996. Mitochondrial rDNA phylogeny of the Asteroidea suggests the primitiveness of the Paxillosida. Molecular phylogenetics 
and evolution, 6, 97-106.

Warren, W. C., and 35 others (2008). Genome analysis of the platypus reveals weak signature of evolution. Nature, 453, doi:10.1038/nature06936. 


\section{FIGURES}

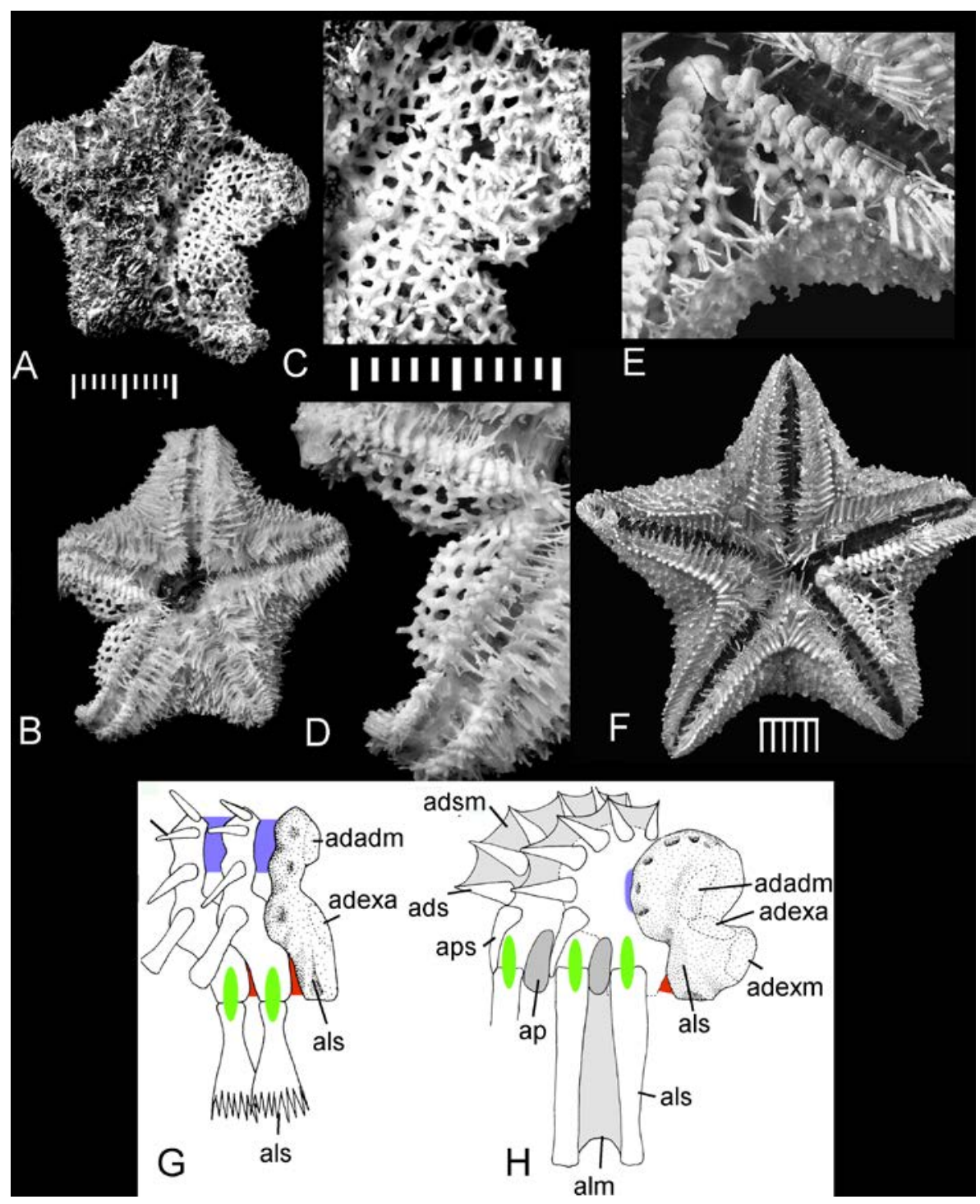

Fig. 1. Morphology of extant pterasterids. A-D, partially dissected individual of Pteraster corynetes Fisher, 1911. A and C, abactinal view, to show reticular pattern of abactinal ossicles when the canopy is removed. Compare with drawing in Fig. 4I. B, D, actinal view, to show interradial groove floored by chevron plates, compare Fig. 4F. E, F, Pteraster pulvillus Sladen, 1889. Actinal view, to show structure of interradial groove beneath canopy, floored with chevron plates. Note how the abactinal spines support the canopy (E). G, H, cartoon to show complex adambulacral morphology in Remaster (G) and Pteraster (H), modified after Gale (2011a, text-fig. 12). Actinolateral spine muscles shown in green; interadambulacral muscles in blue. Key: adadm, adamb-adamb muscle; adexa, adamb extension articulation; adexm, adamb extension muscle; ads, adamb spine; adsm, adambulacral spine membrane; alm, actinolateral membrane; als, actinolateral spine; ap, aperture; aps, apertural spine. Scale bars in $\mathrm{mm}$. 


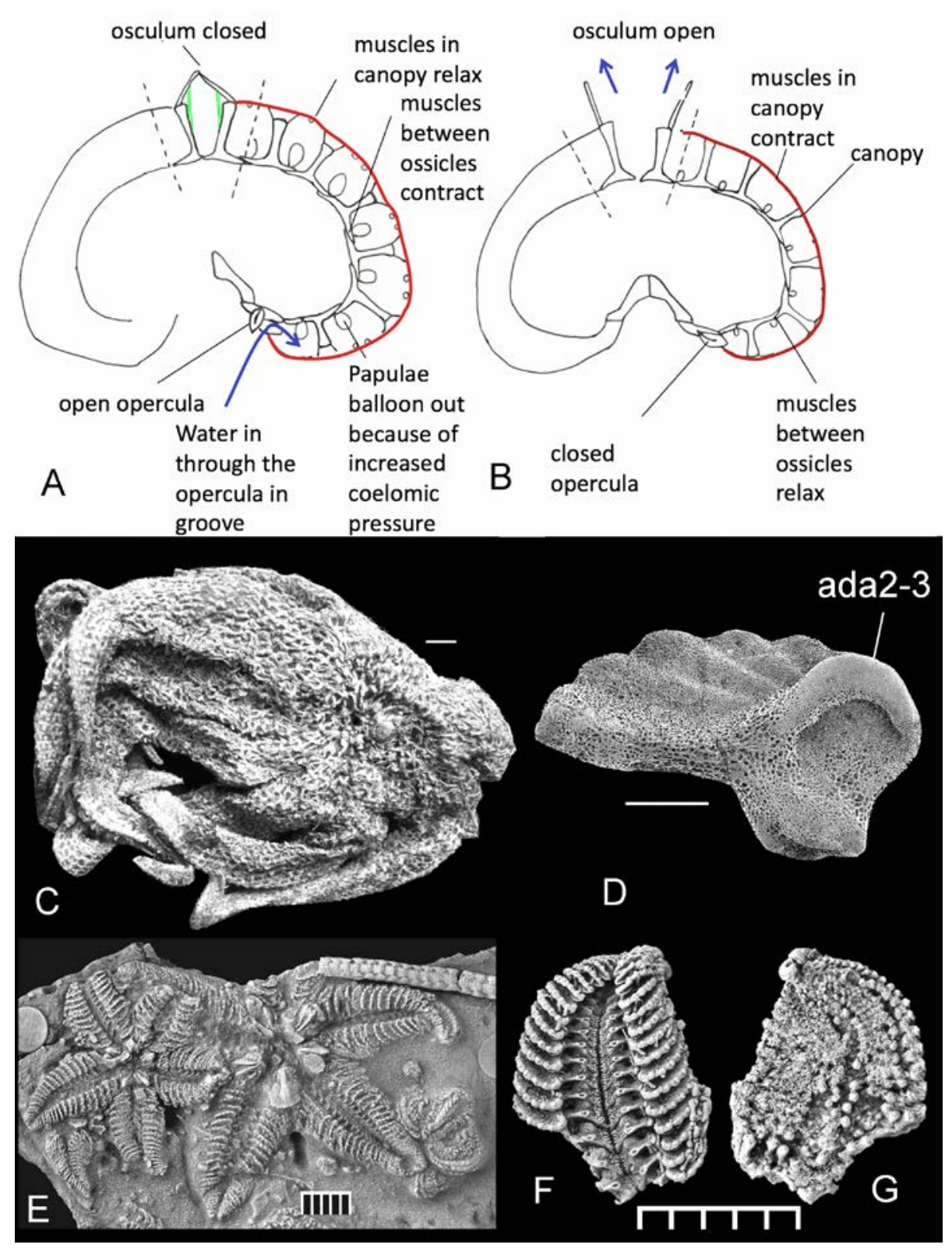

Fig. 2. Respiration in Pteraster tesselatus Ives, 1888, following Nance and Braithwaite (1981) and personal observations. A, inflation phase. The opercular spines on the adambulacrals move to open the opercula, and water flows into the cavity beneath the canopy (red). At the same time, the interabactinal muscles contract, reducing the coelomic volume and causing the papulae to swell. The osculum remains tightly closed by use of powerful muscles which contract to pull down the array of spines. The muscles in the canopy relax. B, deflation phase. The opercula are closed by the opercular spines; the interabactinal muscles relax, and the muscles in the canopy contract. The osculum opens by relaxation of the muscles on the inside of the spines, and water is expelled. It can be seen that opercular spines, interabactinal muscles and muscles closing the osculum by depressing the spines are all essential for this complex manoeuvre. All of these were present in Oxfordian fossils described here. . C, Asthenactis fisheri Alton,1966. Large individual in abactinal aspect. Note numerous arms (10), abactinal skeleton comprised of 
reticulum of ossicles which bear a central cluster of spines (pedicels). British Columbia, Canada. Royal British Columbia Museum, Invertebrate Zoology, no. 004-00055-006. D-G, Tropidaster pectinatus Forbes, 1850. D, adambulacral ossicle in oblique distal aspect. NHMUK EE 14021 (original of Thuy et al. 2011 fig. 5h), E, group of well preserved individuals, actinal surfaces, to show overall form, broad adambulacrals and prominent oral ossicles. NHMUK E 3335. F,G, arm of well preserved individual, in actinal (F) and abactinal (G) aspects. NHMUK EE 13981 (original of Thuy et a. 2011 fig. 5d). Note paxilliform abactinal ossicles with crown of spinelets. D, Pliensbachian, davoei Zone, Mickleton Tunnel, near Chipping Camden, Gloucestershire, UK. D,F,G, Pliensbachian, davoei Zone, Sedan, Ardennes, France (see Thuy et al. 2011 for details). Adambulacral articulations ada2-3 indicated. Scale bars C, 10mm; E-G, 5mm; D, 0.5mm. 

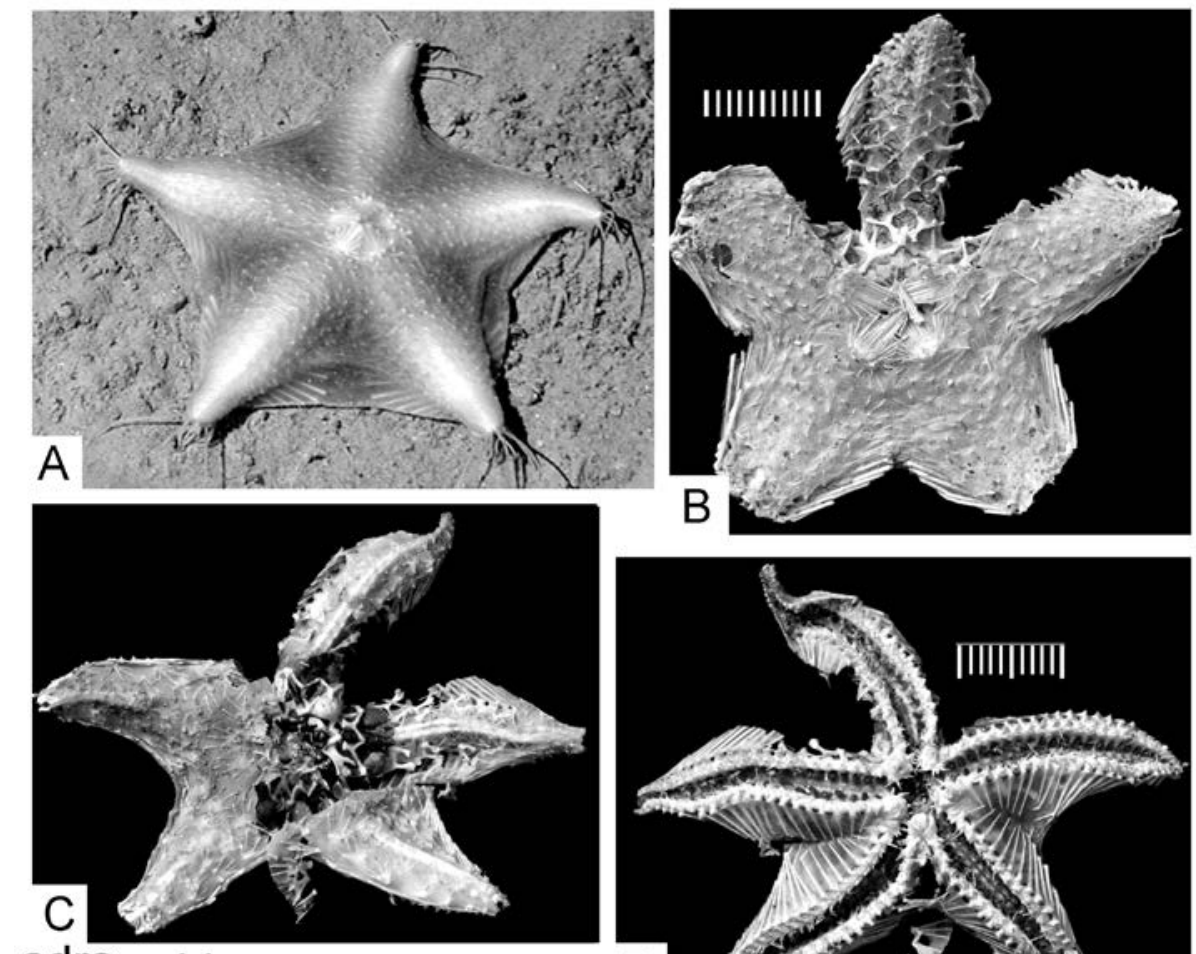

adra adrb

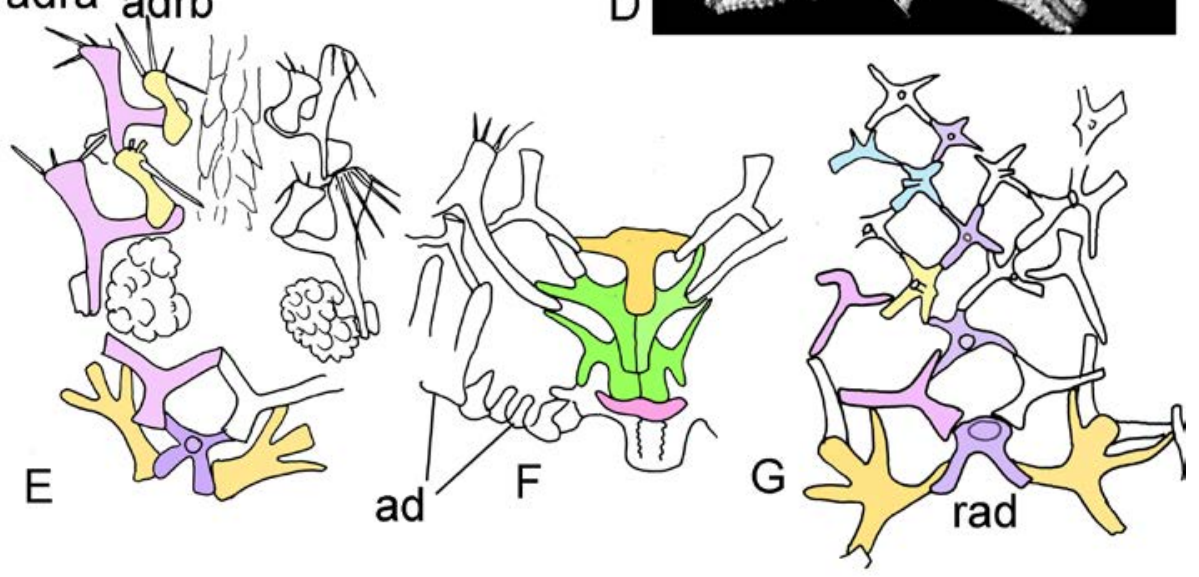

Fig. 3. Species of Hymenaster. A, deep-sea photograph of living Hymenaster ex gr. perissonotus Fisher, 1911. Note the elongated actinolateral spines in membrane, and centrally placed osculum. B, F, G, Hymenaster perissonotus Fisher, 1911. B, G, denuded abactinal surface of individual to show open trellis construction of abactinals. $F$, drawing of actinal aspect of interradius, denuded, to show two chevron ossicles and processes from the adambulacrals contacting the abactinals. C-E, Hymenaster pellucidus Thomson, 1873. C, denuded abactinal surface, D, actinal surface. E, drawing of abactinal surface to show two rows of abactinals on each side of the radius, and absence of radials; the interradial row is labelled as adra, the other as adrb. Primary interradials beige, primary radials/radials mauve, chevrons green, interradial row of abactinals pink (compare with Fig. 4). Ad, adambulacral ossicles. Scale bars in millimetres. 

Fig. 5. A-D, Hymenaster membranaceus Sladen, 1889. A, B, ambulacral ossicles, interior (A) and exterior (B) aspects. C, ambulacral ossicle. D, drawing of in-situ adambulacral spines. ada1, ada2-3, adambulacral articulations: adadm, interadambulacral muscle. als, actinolateral spine. ads, adambulacral spines. ap, aperture. aps, apertural spine. Porcupine Basin, North Atlantic. E, F, Asterina gibbosa Pennant, 1777, Recent, North Sea, United Kingdom. E, abactinal view dissected to show interior. B, actinal view (after Gale $2011 \mathrm{a}, \mathrm{pl} .1 / 3,4)$. Note short arms, broad interradii, imbricating actinal and abactinal ossicles. G, reconstructed adambulacrals 1-5 of Thuyaster fontenoillensis gen. nov., sp. nov., based on ossicles illustrated in Fig. 14. $\mathrm{H}$, drawing of actinal interradius of Korethraster hispidus. I, actinal interradius of Protremaster uniserialis, from the Lower Jurassic of Antarctica. Note the three rows of attachment sites for large spines on the adambulacrals (1-3). H, I after Gale (2011a, text-fig. 25B,C). Note progressive increase in size of adambulacrals distally from oral contact. J-L, muscularisation of abactinal ossicles 
in pterasterids. J shows interabactinal muscle in green, which when contracted, reduces the coelomic volume, causing the papulae to swell. K, primary interradial of Savignaster wardi to show insertion site of abactinal muscle (fine stereom) (original of Gale 2011a, pl. 25, fig. 14; NHMUK EE XXXXXX). Equivalent view of primary interradial of Pteraster corynetes. Scale bars in $\mathrm{A}-\mathrm{C}, \mathrm{K}, \mathrm{L}$ equal $0.5 \mathrm{~mm}$, in $\mathrm{E}, \mathrm{F}$ equal $10 \mathrm{~mm}$. 

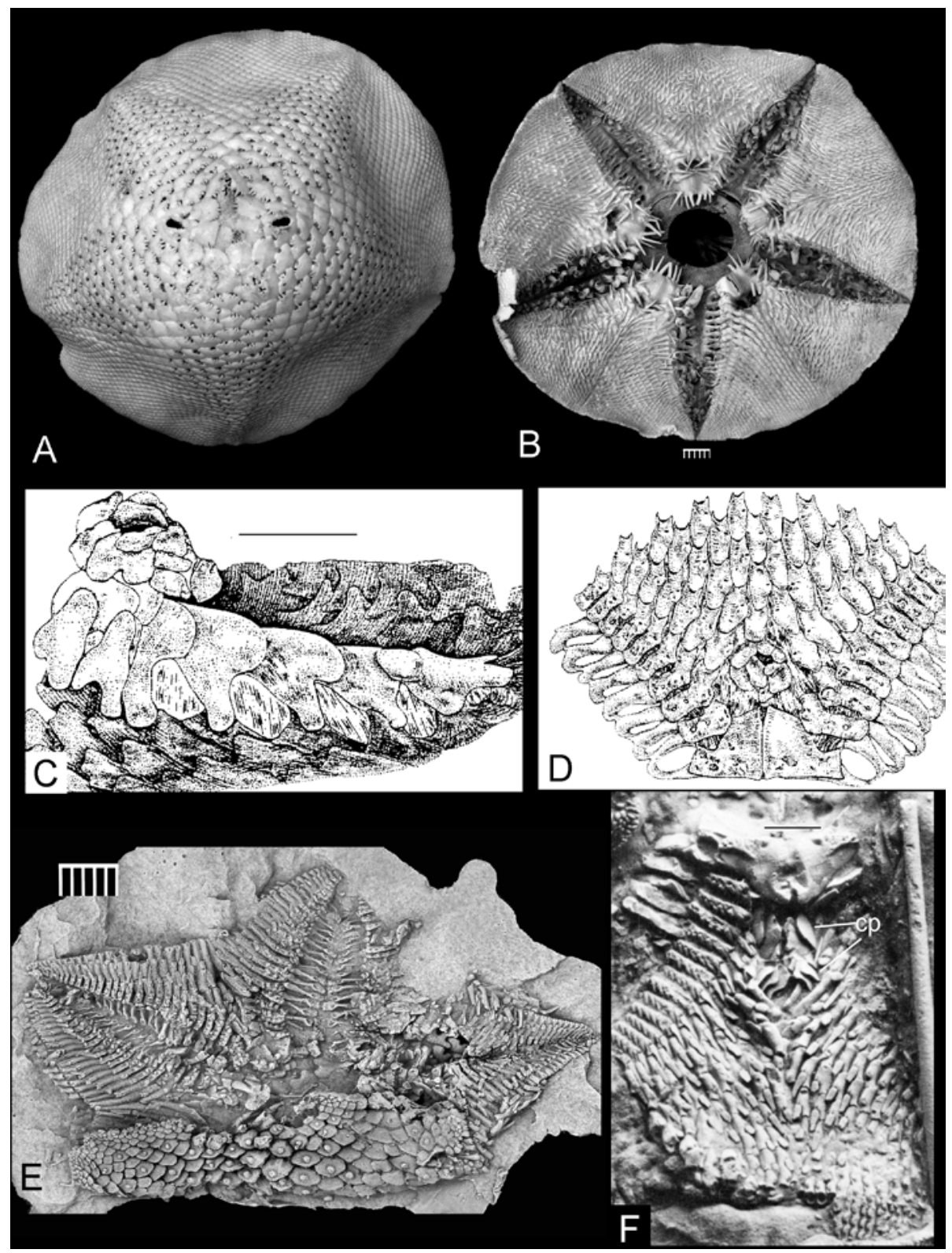

Fig. 6. A-D, Tremaster mirabilis Verrill, 1879. A, B, large individual in abactinal (A) and actinal (B) aspects (original of Clarke and Downey 1992, pl. 44, figs A, B), Newfoundlands Banks, NHMUK Zoology 1968.4.11.11. C, D, drawings of dissected T. mirabilis (after Jangoux 1982, fig. 1C, D). C shows the internal view of the chevron-plate-lined duct leading from the actinal to abactinal surface. D shows the denuded actinal surface with two large oral ossicles (bottom) and the opening of the internal duct. $E$, cast of the unique holotype of Protremaster uniserialis Smith and Tranter, 1985. Note that the specimen has folded obliquely and shows both actinal and abactinal surfaces. Sinemurian, Lower Jurassic, Alexander Island, Antarctic Peninsula, BAS KG 2986.17. F, actinal aspect of interradius, holotype of Mesotremaster zbindeni Hess, 1981. The chevron plate-lined duct is exposed on the actinal surface (cp). Figured after Hess 1981, pl. 2), holotype, NMB no. M9550, middle Oxfordian, Ruchenette, Switzerland. Scale bars equal $5 \mathrm{~mm}$. 


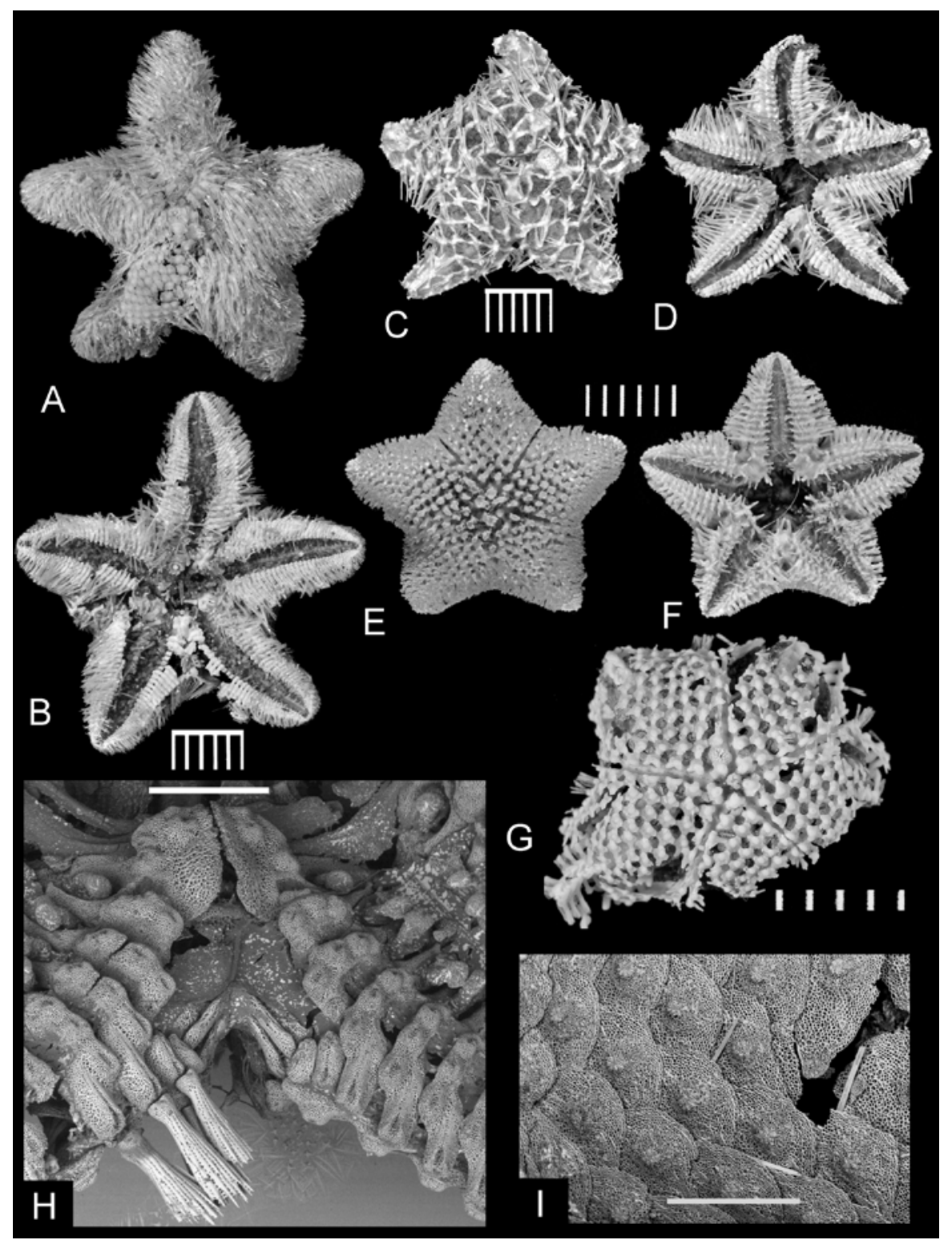

Fig. 7. Living korethrasterids. A, B, I, Korethraster hispidus Thomson, 1873. A, abactinal view. B, actinal. I, denuded abactinal surface. C, D, Peribolaster biserialis Fisher, 1911. C, abactinal. D, actinal views. E-H, Remaster gourdoni, Koehler, 1912, abactinal (E) and actinal (C) views. $G$, denuded abactinal surface. $H$, actinal interradial view to show chevron plates, adambulacrals and actinolateral spines. A, B, I, Faroe Islands, Natural History Museum, Torshavn, 739. C, D, Bering Sea, USNM 31732. E-G, Falklands Islands, NHM Zoology 1948.3.16.546. Scale bars equal $5 \mathrm{~mm}$. 
Fig. 8. Abactinal, ambulacral and circumoral ossicles of fossil and living pterasterids and peribolasterids. A-C, E, G-M, Hansaster trimbachensis (Gale 2011). A, E, G, H, L, O, abactinal ossicles. Note delicate, elongated pedicels $(G, H)$ and sites for insertion of interabactinal muscles (G, L, M) NHMUK EE 16559-64. B, C, I, ambulacral ossicles. NHMUK EE 16565-7. J, K, circumoral ossicles, NHMUK EE 16568-9. F, possible radial ossicle of Becuaster fusiliformis gen. nov., sp. nov., NHMUK EE 16570. D, N, M, P-S, Pteraster corynetes Fisher, 1916. D, P, Q, S, abactinal ossicles. M, N, circumoral ossicles. R, ambulacral ossicle, actinal view. A-C, E, G-M, lower Oxfordian, Cardioceras bukowskii Subzone, basal Couches de Passage, Andelot-Morval, Jura, France, sample And 1-5 (Fig. 20A). F, lower Oxfordian, Cardioceras praecordatum Subzone, upper Marnes à $C$. renggeri, Andelot-Morval, Jura, France, sample And 9 (Fig. 20A). Pteraster corynetes, Recent, Philippines. Scale bars equal $0.5 \mathrm{~mm}(\mathrm{~A}-\mathrm{D}, \mathrm{H}-\mathrm{R})$ and $0.2 \mathrm{~mm}(\mathrm{E}-\mathrm{G}, \mathrm{S})$. 
Fig. 9. Primary radial ossicles of fossil and extant pterasterids. $A, B, F-H$. Hansaster trimbachensis (Gale, 2011). A, B, complete pr, base slightly coated with calcite cement, distal (A) and proximal (B) views. NHMUK EE 16571. F-H, well-preserved pr, in distal (A), lateral (B) and proximal (C) views. NHMUK EE 16572. C-E, I, J, R, Propteraster amourensis gen. nov., sp. nov. C-E, well-preserved pr, in proximal (C), lateral (D) and distal (E) views. Holotype, NHMUK EE 16573. I, J, R, pedicels with base broken off, proximal aspect. NHMUK EE 16574-6. Paratypes. K-M, Pteraster coynetes Fisher, 1916. Recent, Phillippines. Pr in distal (K), proximal L) and abactinal (M) views. O-Q, Pteraster temnochiton Fisher, 1910. Recent, Alaska. N, S, Pteraster acicula Downey, 1970. Pr in distal $(\mathrm{N})$ and proximal $(\mathrm{O})$ views, Recent, Florida. A, B,F-H, lower Oxfordian, Cardioceras bukowskii Subzone, basal Couches de Passage, Andelot-Morval, Jura, France, sample And 1-5 (Fig. 20A). C-E, I, J, R, lower Oxfordian, Cardioceras praecordatum Subzone, upper Marnes à C. renggeri, Andelot-Morval, Jura, France, sample And 9 (Fig. 20A). bp, basal part of pr. co, column of pr, divided into shaft, s and head, h. pp, proximal process, 
$\mathrm{dp}$, distal process. pc, proximal cavity. Ps, proximal spur for insertion of muscles depressing spines. Scale bars equal $0.5 \mathrm{~mm}(\mathrm{~A}-\mathrm{H}, \mathrm{K}-\mathrm{M}, \mathrm{O}-\mathrm{Q})$ and $0.2 \mathrm{~mm}(\mathrm{~J}, \mathrm{~N}, \mathrm{R}, \mathrm{S})$.

Fig. 10. Mouth frame (oral, circumoral, odontophore), chevron ossicles and primary interradials of fossil and extant pterasterids. A, B, oral ossicle of Propteraster amourensis gen. nov., sp. nov., paratype, NHMUK EE 16577, in radial (A) and interradial (B) views. CE, I, J, M, O-Q, S, T, Hansaster trimbachensis (Gale, 2011). C-E, odontophore in distal (C), proximal (E) and actinal (D) aspects, NHMUK EE 16578. I, J, oral ossicle in radial (I) and interradial (J) views. NHMUK EE 16579. M, N, Q, T, chevron ossicles, abactinal aspect. NHMUK EE 16580-3. P, S, primary interradial ossicles, actinal $(P)$ and abactinal (S) aspects. NHMUK EE 16584-5. F-H, K, L, N, R, Pteraster coynetes Fisher, 1916. Recent, Phillippines. F-H, odontophore, same views as $H$. trimbachensis. $K$, L, oral ossicle in radial $(K)$ and interradial $(L)$ aspects. $N, R$, chevron plates, abactinal views. $A, B$, lower Oxfordian, Cardioceras praecordatum Subzone, upper Marnes à C. renggeri, Andelot- 
Morval, Jura, France, sample And 9 (Fig. 20A). C-E, I, J, M, O, P, Q, S, T, lower

Oxfordian, Cardioceras bukowskii Subzone, basal Couches de Passage, Andelot-Morval, Jura, France, sample And1-5 (Fig. 20A). Scale bars equal $0.5 \mathrm{~mm}$ (C-E, I-N, P-R) and $0.2 \mathrm{~mm}(\mathrm{~A}, \mathrm{~B}, \mathrm{~F}-\mathrm{H}, \mathrm{O}, \mathrm{P}, \mathrm{S}, \mathrm{T})$.

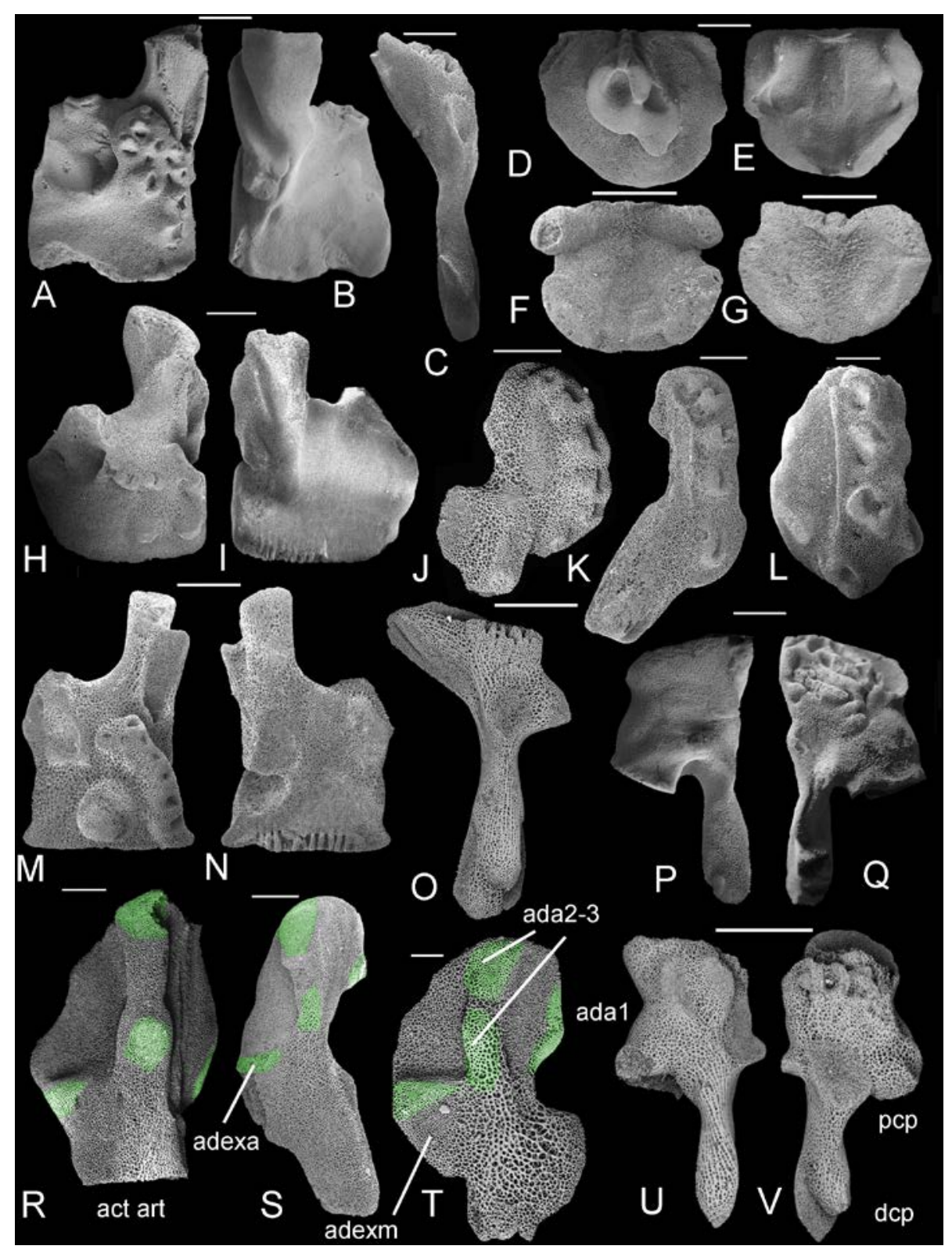

Fig. 11. Ossicles of extant tremasterines, korethrasterids and pterasterids. A-E, $L, P, Q$, R, Tremaster mirabilis Verrill, 1879. A, B, oral ossicle, radial (A) and interradial (B) views. C, ambulacral. D, E, odontophore. L, adambulacral, actinal view. P, Q, circumoral ossicle. F, H, I, K, S, Peribolaster lictor Fell, 1958. F, odontophore. H, I, oral ossicle. K, S, adambulacral ossicle. G, Pteraster pulvillus Sladen, 1889. Odontophore. M, N, U, V, Pteraster coynetes Fisher, 1916. M, N, oral ossicle. U, V, circumoral. J, T, Pteraster tesselatus Ives, 1888. Tremaster mirabilis, Victoria Museum, F 1101124. Macquaqrie Island, Tasmania. Peribolaster lictor Fell, 1958. NIWA 23057, New Zealand, 43.9000S, 
$179.2333^{\circ} \mathrm{W}$, Pteraster corynetes, Phillippines, purchase. Pteraster tesselatus, Washington State, USA. . Note the similarity in adamb construction between Tremaster mirabilis (R), Peribolaster lictor (S) and Pteraster ( $\mathrm{T})$. The abrupt abradial margin in $T$. mirabilis marks the contact with the actinal ossicles. In velatids (P. lictor and Pteraster) an ambulacral extension is present, which extends to the ambitus. Scale bars equal $5 \mathrm{~mm}$ (A, B, D, E, P, Q(, 1 mm (F-I, L, R) and $0.5 \mathrm{~mm}(\mathrm{~J}, \mathrm{~K}, \mathrm{M}, \mathrm{N}, \mathrm{O}, \mathrm{S}-\mathrm{V})$.

Fig. 12. Adambulacral ossicles of fossil and extant korethrasterids and pterasterids. A, B, G, H, Hansaster trimbachensis (Gale, 2011). G, H, original of Gale (2011a, pl. 23, figs 1, 2), holotype, NMB M 11143. A,B, NHMUK EE 16586. C, D, Becuaster fusiliformis gen. nov., sp. nov., NHMUK EE 16587, holotype. I, J, Propteraster amourensis gen. nov., sp. nov, NHMUK EE 16588, holotype. K, L, Savignaster wardi Gale, 2011a, adambulacral (original of Gale 2011a, pl. 23, figs11,12), NHMUK EE 13635. E, F, Peribolaster lictor Fell, 1958. New Zealand. N, O, Pteraster temnochiton Fisher, 1910. Recent, Alaska. M, P, Pteraster coynetes Fisher, 1916. Recent, Phillippines. A, B, lower Oxfordian, Cardioceras bukowskii Subzone, basal Couches de Passage, Andelot-Morval, Jura, France, sample And 1-5 (Fig. 20A). C, D, I, J, lower Oxfordian, Cardioceras praecordatum Subzone, upper 
Marnes à C. renggeri, Andelot-Morval, Jura, France, sample And 9 (Fig. 20A). G, H, upper Oxfordian, Rumperl, southwest of Trimbach, near Olten, Canton Solothurn, Switzerland. Key; adadm, adamb-adamb muscle insertion; adexa, adamb extension articulation. adexm, adamb extension muscle. ads, adamb spine site. als, actinolateral spine site. aps, apertural spine site. Scale bars equal $1 \mathrm{~mm}(\mathrm{G}, \mathrm{H})$ and $0.5 \mathrm{~mm}(\mathrm{~A}-\mathrm{F}, \mathrm{J}-\mathrm{P})$.

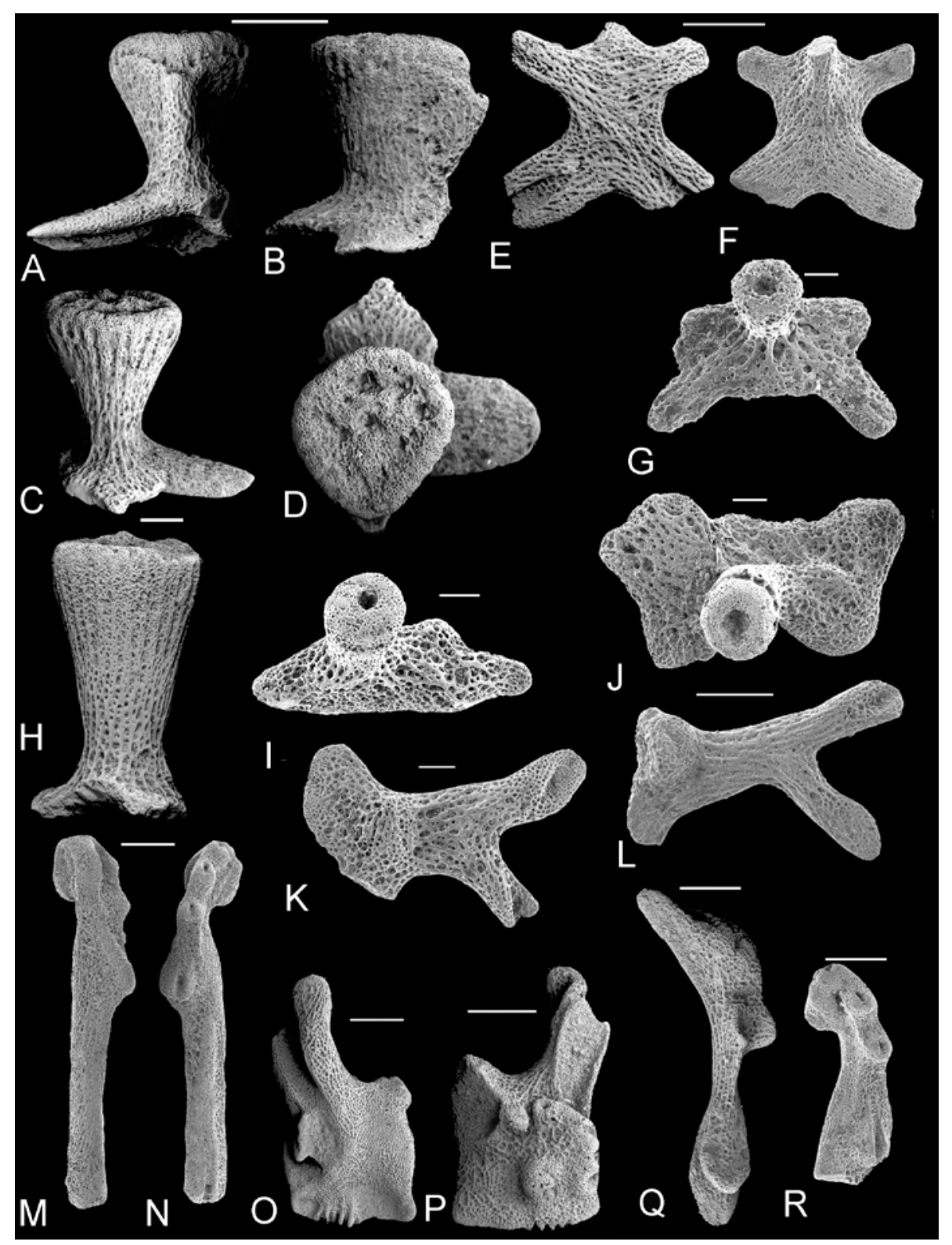

Fig. 13. Ossicles of Savignaster wardi Gale, 2011a. A-D, primary radial ossicle, in proximal (A), lateral (B), distal (C) and abactinal (D) views, NHMUK EE 16589. E, F, primary interradial ossicle, abactinal (E) and actinal (F) views (original of Gale 2011, pl. 25, figs13-15), NHMUK EE 13632. H, large primary radial ossicle, base broken, distal view. NHM UK EE 16590. G, I, J, abactinal ossicles, abactinal view. G, original of Gale (2011, pl. 24, fig. 10), NHMUK EE 13639. I, original of Gale (2011, pl. 24, fig. 12), NHMUK EE 13940. J, original of Gale (2011, pl. 24, fig. 7), NHMUK EE 13941. K, L, chevron ossicles. 
K, original of Gale (2011a, pl. 25, fig. 12), NHMUK EE 13628. L, original of Gale (2011, pl. 24, fig. 6), NHM UK EE 13628. M, N, R, adambulacral ossicles. M, N, original of Gale (2011a, pl. 23, figs 11,12), NHMUK EE 13635. R, NHMUK EE . O, P, oral ossicles, O, interradial view, original of Gale (2011a, pl. 23, fig. 7), NHMUK EE 13613. P, radial view, NHMUK EE 16592. Q, ambulacral ossicle, actinal view, original of Gale (2011a, pl. 24, fig. 6), NHMUK EE 13618. All from the Couches de Effingen, upper Oxfordian, bifurcatus Subzone, Savigna, Départment de Jura, France. Scale bars equal $0.5 \mathrm{~mm}(\mathrm{~A}-\mathrm{D}, \mathrm{H}, \mathrm{L}-\mathrm{P})$ and $0.2 \mathrm{~mm}(\mathrm{E}, \mathrm{F}, \mathrm{I}, \mathrm{J}, \mathrm{K}, \mathrm{Q}, \mathrm{R})$.

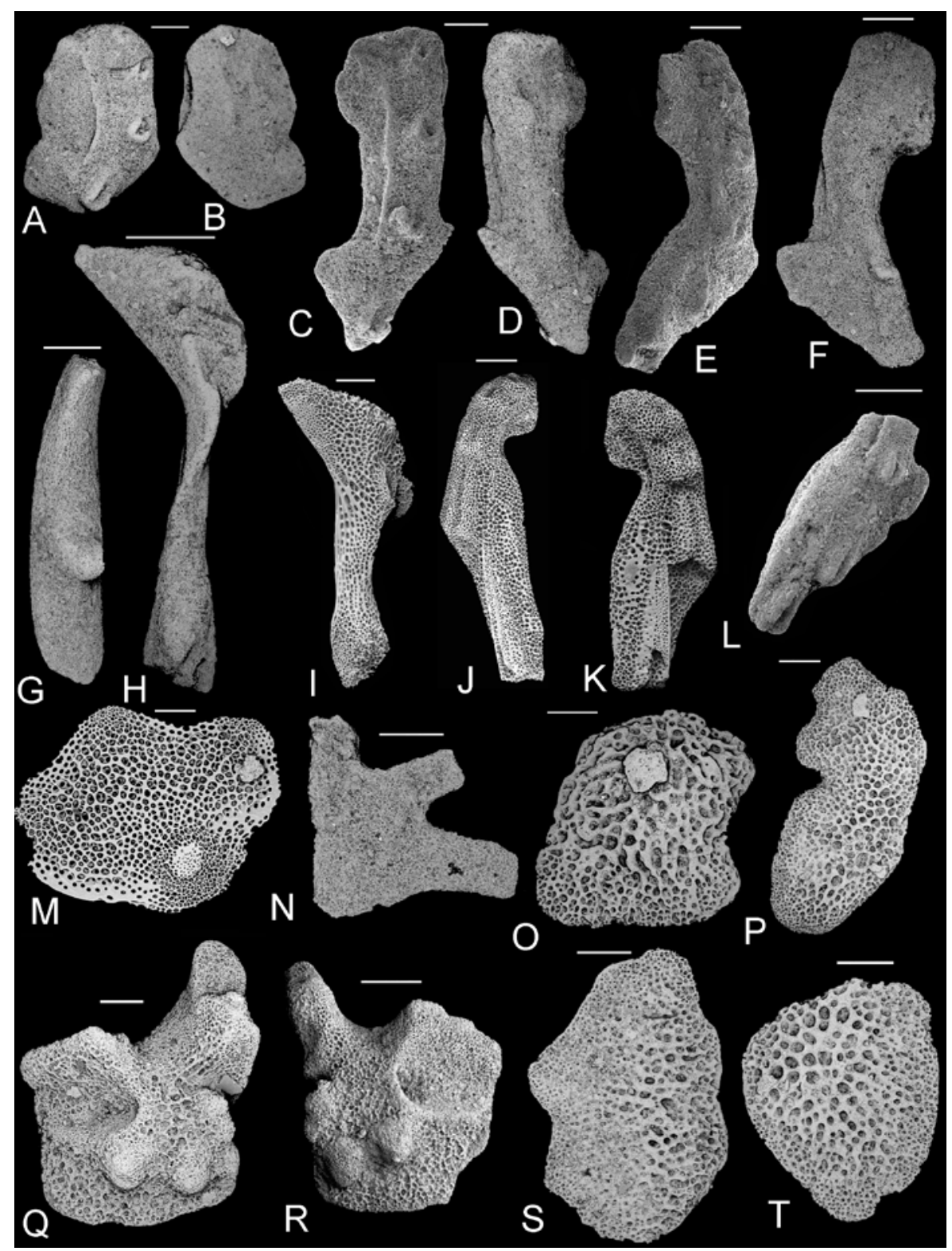

Fig. 14. A-H, L, N-T, Thuyaster fontenoillensis gen. nov., sp. nov. A-F, L, adambulacral ossicles. A, B, proximal adambulacral in actinal (A) and actinal (B) views, paratype, NHMUK EE 16593. C, D, adambulacral in actinal (C) and abactinal (D) views, holotype, NHMUK EE 16594. E, F, median adambulacrals, paratypes, NHMUK EE 16595-6. L, 
fragmentary paratype adambulacral, NHMUK EE 16597. G, H, ambulacral ossicles. NHMUK EE 16598-9. N, interradial chevron ossicle, NHMUK EE 16600. O, P, S, T, abactinal ossicles, NHM UK EE 16601-4. Q, R, oral ossicles, radial views. NHMUK EE 16605-6. I-K, M, Korethraster hispidus Thomsen, 1873. I, ambulacral ossicle, actinal view. $\mathrm{J}, \mathrm{K}$, adambulacral ossicles. $\mathrm{M}$, abactinal ossicle. A-H, L, N-T, middle Hettangian, Alsaites liasicus Zone, Marnes de Jamoigne Formation, Fontenoille, K. Province of Luxembourg, Belgium, bed C2 (see Delsate et al. 2002 for details). I-K, M. Korethraster hispidus, Faroe Islands, Zoological Museum, Copenhagen. Scale bars equal $0.5 \mathrm{~mm}(\mathrm{~A}-\mathrm{H}, \mathrm{L}, \mathrm{N}-\mathrm{P}, \mathrm{S}, \mathrm{T})$ and $0.2 \mathrm{~mm}(\mathrm{I}-\mathrm{K}, \mathrm{M}, \mathrm{Q}, \mathrm{R})$.

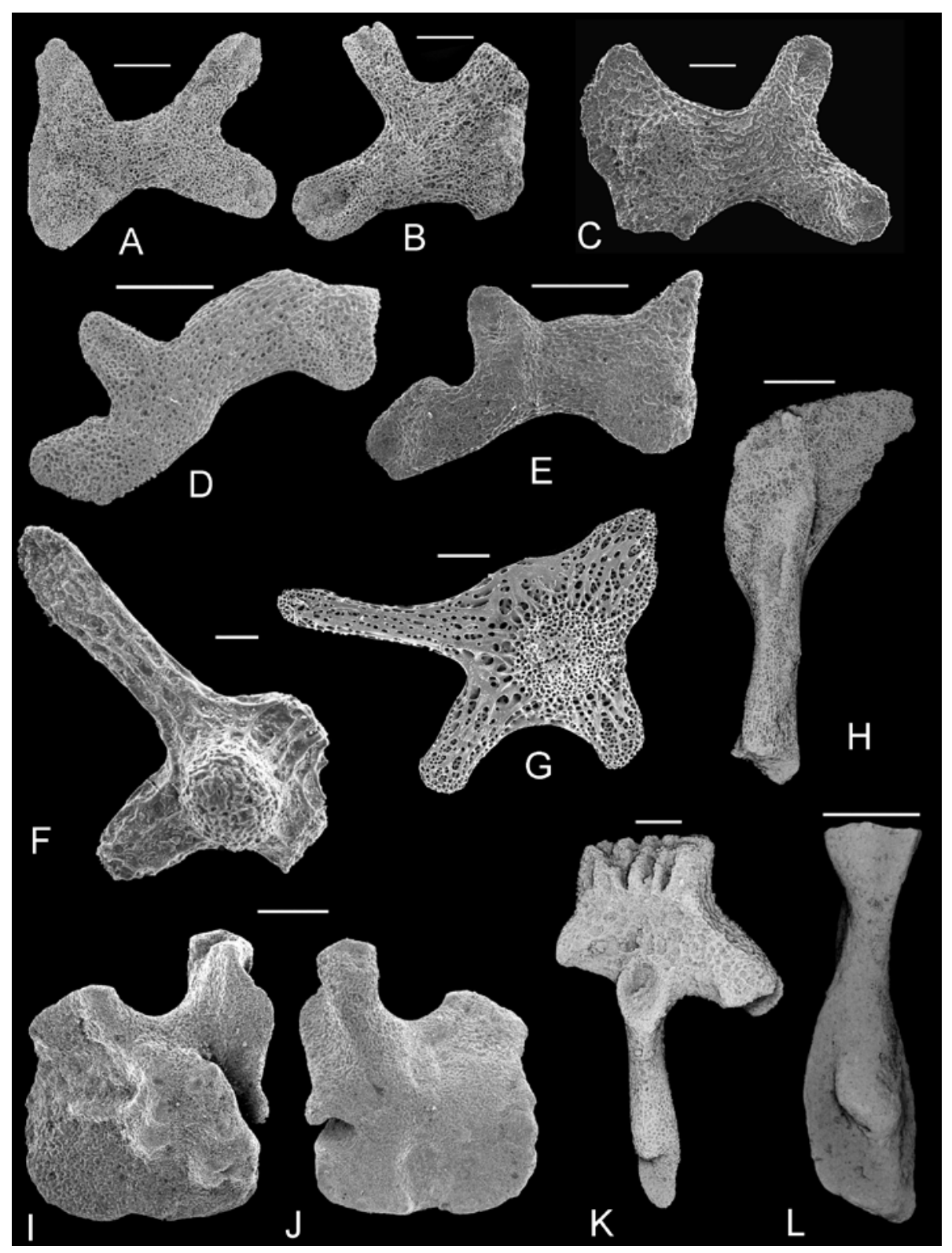

Fig. 15. Velatid asteroid ossicles from Sedan, France. A-E, interradial chevron ossicles of an unknown velatid. NHMUK EE 16607-16611. F, G, radial ossicle (F) and abactinal (G) of a velatid that is close to Longwyaster gen. nov. F, NHMUK EE 16612; G, EE 16613. H, L, 
ambulacral ossicles of a velatid. I, J, oral ossicle of a velatid. NHMUK EE 16614, 16615. K, circumoral ossicle of a velatid. EE 16616. Lower Jurassic, Pliensbachian, Prodactylioceras davoei Zone, Sedan, Ardennes, France (see Thuy et al. 2011, for locality details). Scale bars equal $1 \mathrm{~mm}(\mathrm{I}, \mathrm{J}, \mathrm{L}), 0.5 \mathrm{~mm}(\mathrm{~A}-\mathrm{F}, \mathrm{H})$ and $0.2 \mathrm{~mm}(\mathrm{G}, \mathrm{K})$.

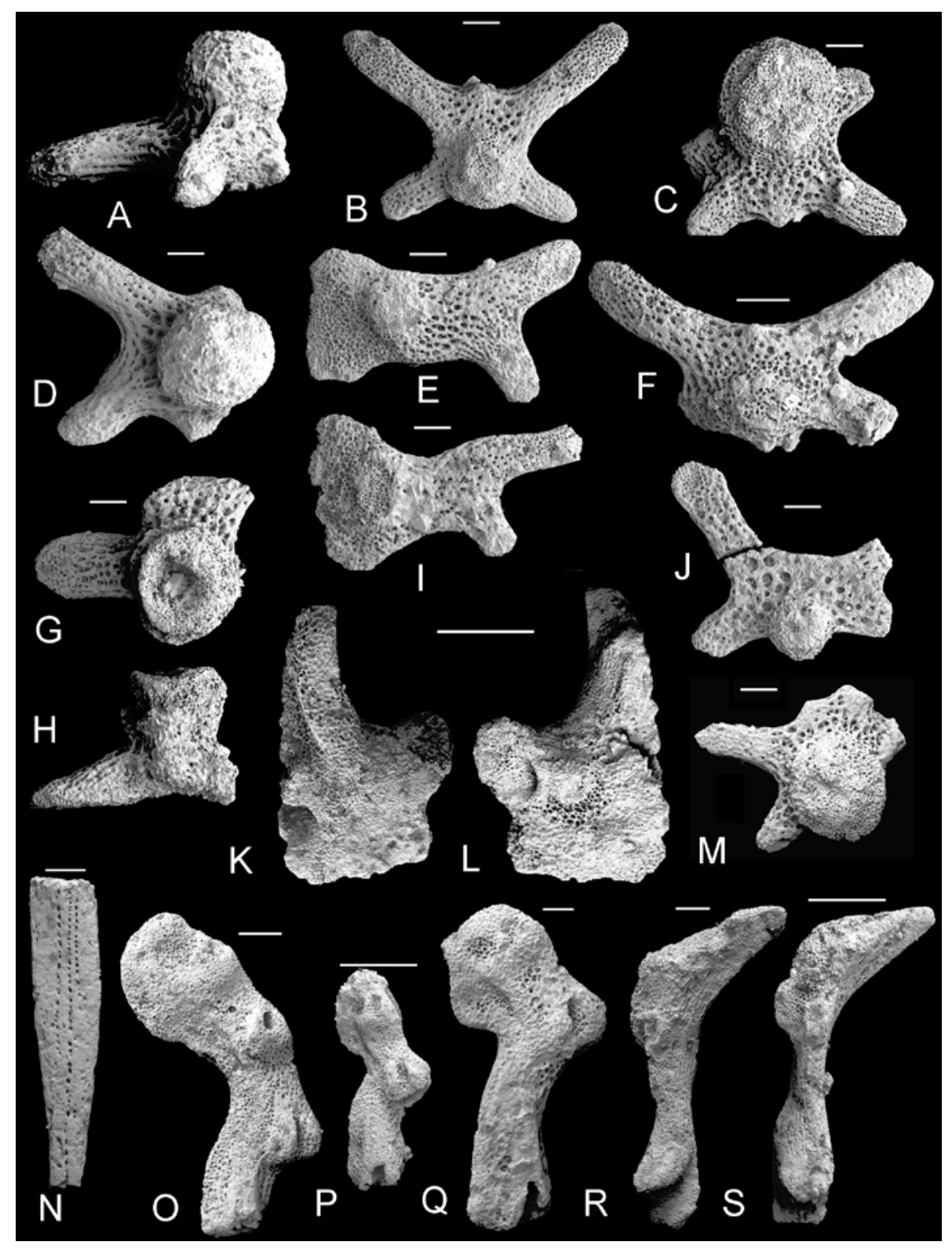

Fig. 16. Longwyaster delsatei gen. nov., sp. nov. Isolated ossicles. A-D, F-H, J, M, abactinal ossicles. A, D, abactinal and lateral views of an abactinal ossicle with a bulbous process. NHMUK EE 16617. B, large proximal radial ossicle. NHMUK EE 16618. C, F, M, abactinal ossicles showing attachment sites for a crown of spines. NHMUK EE 16619-21. $G, H$, primary radial ossicle in abactinal $(G)$ and proximal $(H)$ views. NHMUK EE 16622. J, radial ossicle. NHMUK EE 16623-4. E, I, interradial chevron plates, actinal view. NHMUK EE 16625. K,L, oral ossicle in radial (K) and interradial (L) views. NHMUK EE 16626. N, actinolateral spine. NHM UK EE 16627. O-Q, adambulacral ossicles, actinal view. 
NHMUK EE 16628-30. R, S, ambulacral ossicles, actinal views. NHMUK EE 16631-2. Road cutting on N52; lower Bajocian, Laeviuscula Zone (see Delsate 1993; Thuy 2015), Longwy Formation, from lower of two marl beds described by Delsate (1993), Longwy, Ardennes, France. Scale bars equal $0.5 \mathrm{~mm}(\mathrm{~K}, \mathrm{~L}, \mathrm{P}, \mathrm{S}), 0.2 \mathrm{~mm}(\mathrm{~A}-\mathrm{J}, \mathrm{M}-\mathrm{O}, \mathrm{R})$ and 0.1 $\mathrm{mm}(\mathrm{Q})$.

Fig. 17. Velatid adambulacrals from Andelot-Morval, France. A-E, Hansaster trimbachensis (Gale 2011a). A, B, NHMUK EE 16586. C, NHMUK EE 16633. D, E, NHMUK EE 16634. F, G, J-L, Propteraster amourensis gen. nov., sp. nov. F, G, actinal and abactinal views of holotype, NHMUK EE 16588. J, K, actinal and abactinal views of paratype, NHMUK EE 16637. L, actinal view of paratype, NHMUK EE 16638. H, I, M, Becuaster fusiliformis gen. nov., sp. nov. $\mathrm{H}, \mathrm{I}, \mathrm{M}$, paratypes in actinal and views. NHMUK EE 16635-6, 16639. A-E, samples And 1-5, unit E, Couches de Passage, C. bukowskii Zone, lower Oxfordian (Fig. 20A). F-M, sample And 9, Marnes à C. renggeri, C. 
praecordatum Zone, lower Oxfordian, Andelot-Morval, Jura (see Fig. 20A). Scale bars equal $0.5 \mathrm{~mm}(\mathrm{~A}, \mathrm{~B}, \mathrm{~F}-\mathrm{K}, \mathrm{M})$ and $0.2 \mathrm{~mm}(\mathrm{D}, \mathrm{E}, \mathrm{L})$.

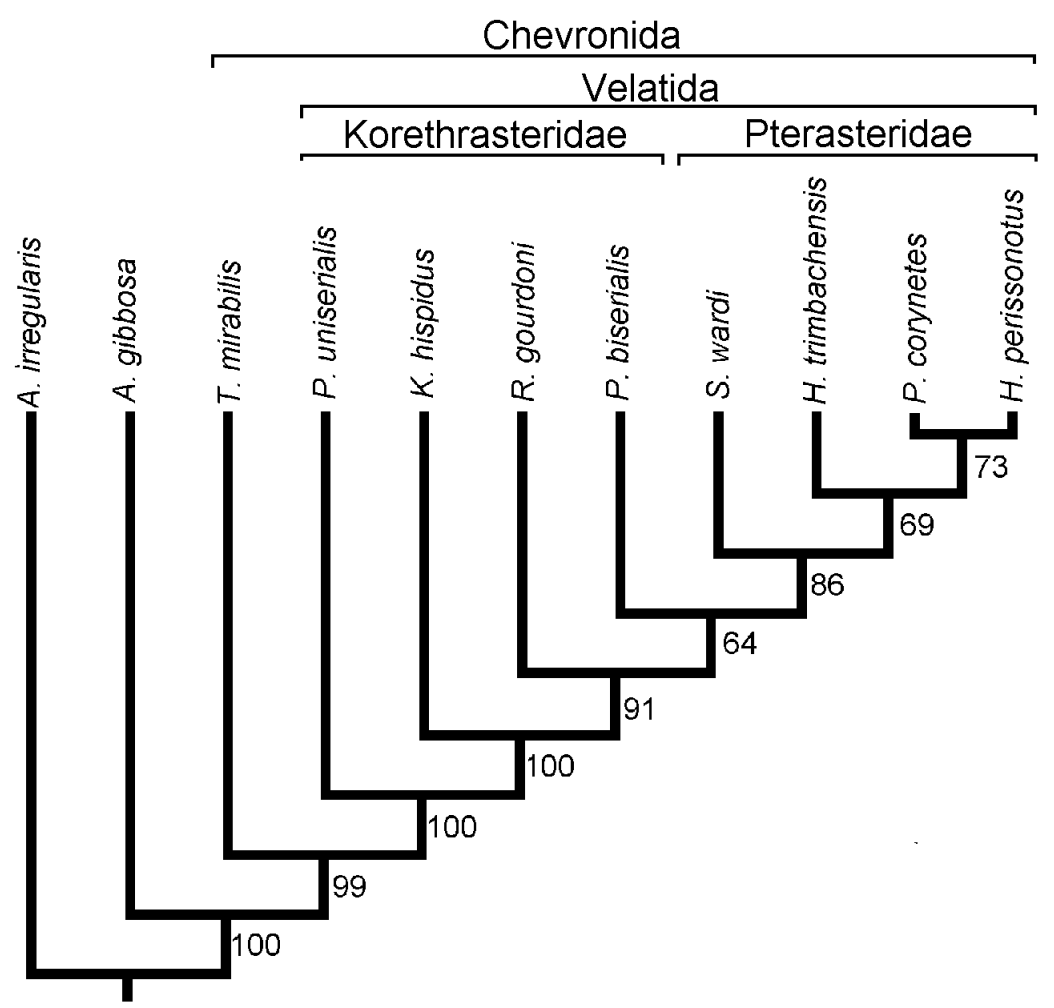

Fig. 18. Cladogram of possible relationships between 11 species of asteroid, based on 53 characters. Bootstrap support values shown. 


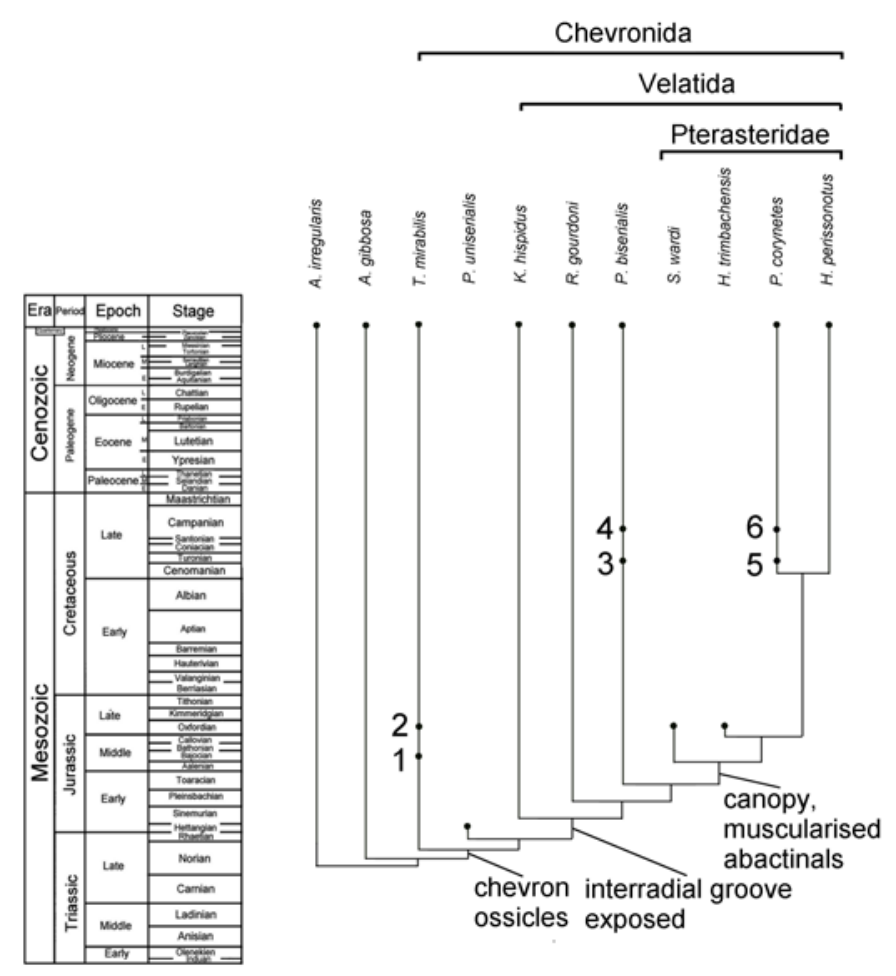

Fig. 19. Stratigraphically calibrated cladogram, as shown in Figure 18. 1, 2, refer to records of Mesotremaster from the Bajocian (M. felli) and Oxfordian (M. zbindeni) which are closely related to the extant $T$. mirabilis. 3, 4 refer to unpublished records of a korethrasterid close to Peribolaster from the Cenomanian and Campanian of the UK. 5, 6, are records of Pteraster spp. from the Upper Cretaceous (Campanian and Maastrichtian) of northwest Europe. It is clear that a large part of the evolution in the group took place either in the Early or Middle Jurassic. 

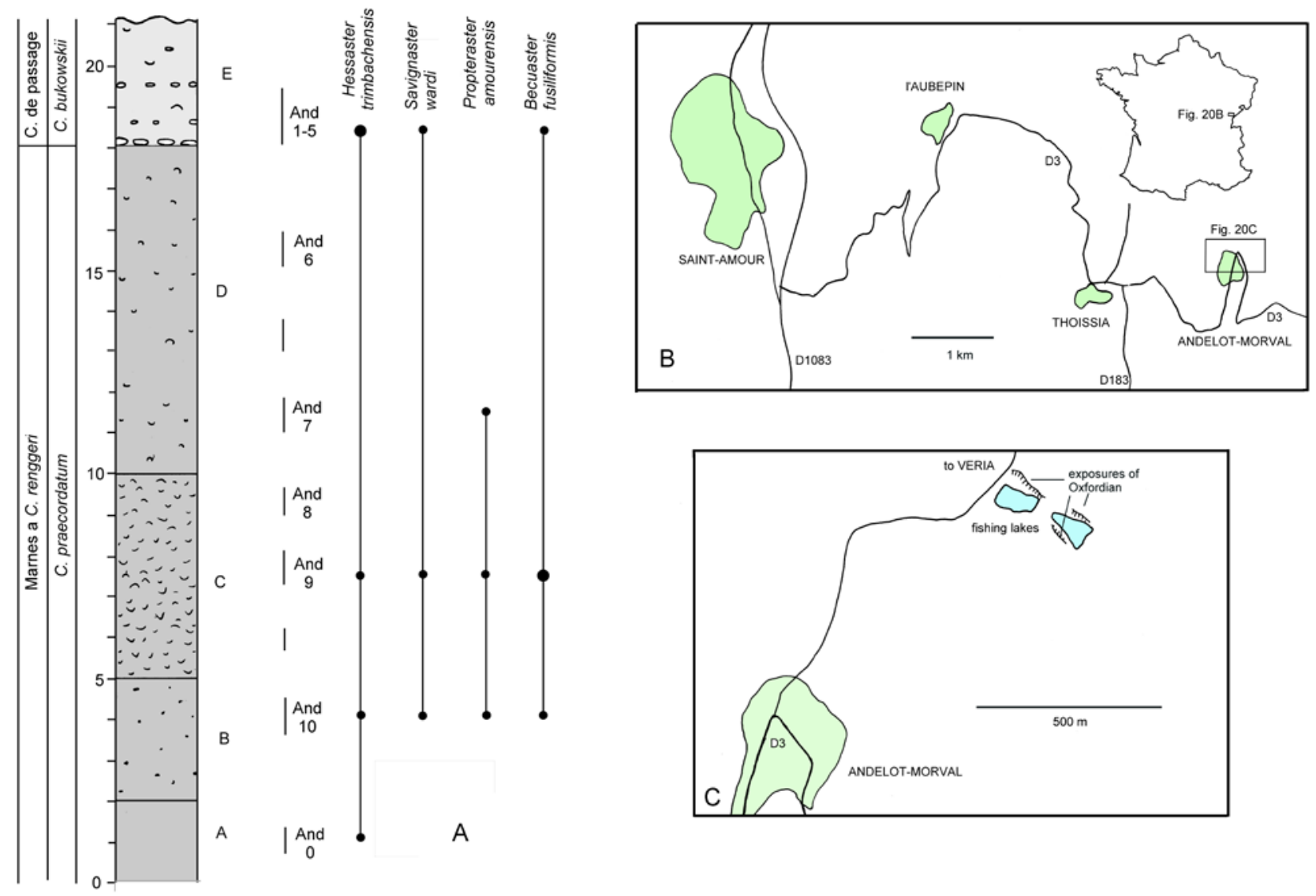

Fig. 20. A, Log of the succession exposed in the fishing lake section at Andelot-Morval. B, map of the French region indicated, to show the location of Andelot-Morval. C, Map of the northern part of Andelot-Morval to show location of Oxfordian exposures. 
Table 1. Character matrix for Figure 18.

Appendix 1.

Character list

- 1) body flat (0), convex-abactinally, flat actinally (1)

- 2) arms very short ( $R=r)(0)$, arms produced ( $R>r)(1)$

- 3) canopy absent (0), canopy covering body present (1)

- 4) interradial skeletal structures absent (0), low pillar of ossicles adjacent to odontophore (1) internal calcified ducts leading from actinal to abactinal surface (2) externally open grooves floored by chevron plates (3)

- 5) internal ducts are single structure (0), with separate vertical chimney and chevron region (1)

- 6) narrow actinal opening to interradial ducts (0), broad interradial opening displays chevron plates (1)

- 7) chevron plates elongated (0), short, broad (1)

- 8) chevron plates simple flat bar form (0), with bifid lateral extension (1)

- 9) numerous (8-12) chevron plates present (0), few (1)

- 10) abactinals in irregular rows (0) diagonal radial-convergence pattern (1)

- 11) abactinal ossicles imbricate, tile-like with tiny notches for papulae (0), large notches for papulae (1) form open trellis-like reticulum (2)

- 12) abactinal plates with nonspecialised contacts (0), each flange on the base of abactinal possesses articular surfaces and attachment site for interabactinal muscles (1)

- 13) abactinal ossicles form diagonally arranged tessellation (0), set in transverse rows (1)

- 14) small papulae (0), large, elongated papulae (1)

- 15) papulae loose (0) attached to pedicel (1)

- 16) primary circlet inconspicuous with small interstitial ossicles (0), comprises 5 large radials, 5 interradials, 1 centrale all in contact (1) central membrane surrounded by primary radials and interradials (2)

- 17) Centrale large (0) small (1) replaced by small ossicles in membrane (2)

- 18) Primary interradials flush with primary radials (0) inset beneath radials (1)

- 19) Primary interradials carry spines (0) naked (1) 
- 20) Primary interradials flat (0), concave abactinally, convex actinally (1)

- 21) Primary interradials oval (0) with 5 elongate processes for articulation (1)

- 22) Primary radials oval (0), irregularly lobed (1), with Y-shaped processes which articulate with adjacent abactinals (2)

- 23) Primary radials smooth, flat (0), with stubby central spine base (1) with low conical pedicel (2), with tall flattened pedicel (3)

- 24) Pedicel of primary radial lacks muscle insertion site on interior face (0), large muscle insertion site present (1)

- 25) large number of abactinal rows (8-12) (0), fewer (4-5) (1) very few (2)

- 26) no specialised articulations between adambs and abactinals (0), tall articular flanges from adambs contact abactinal (1)

- 27) pedicel with parallel sides (0),pedicel vase-shaped, expanded abactinally (1)

- 28) abactinal spines scattered (0), restricted to small central boss (1), attached to elongated pedicel (2)

- 29) abactinal spines short, granular/thorny (0), elongated, hyaline (1)

- 30) abactinal spines separate (0), united by a membrane (1)

- 31) spiraculae absent (0), present (1)

- 32) osculum absent (0), present (1)

- 33) tubefeet biserial (0) quadriserial (1)

- 34) adambs broad, rectangular (0), with adamb extension (1), with no amb extension (2)

- 35) adambulacral extension muscle absent (0) present (1)

- 36) adambulacral extension articulation absent (0), present (1)

- 37) first 1-3 adambulacrals as broad as distal ones (0), first 1-3 adambs narrow (1)

- 38) lateral adambulacral margin inset on actinal surface (0), defines ambitus (1)

- 39) adambulacrals weakly imbricate (0), strongly imbricate (1)

- 40) adambulacrals not flattened (0), strongly flattenened (1)

- 41) discrete ada2,3 articulations (0), ada2/3 confluent, positioned on transverse ridge (1)

- 42) large actinolateral adamb spine absent (0), present (1)

- 43) apertures between adambs absent (0) present (1)

- 44) apertural spines absent (0) present (1)

- 45) actinolateral adamb spines unwebbed (0) webbed (1)

- 46) ambulacrals without flattened heads (0) flattened (1)

- 47) ambulacral heads do not imbricate (0) imbricate strongly proximally (1) 
- 48) ambulacral heads without distal flange (0), present, short (1), elongated as much as proximal one (2)

- 49) ambulacral base with discrete articular surfaces ada1a,b, ada2,ada3 (0), ada1a/2, ada1b/3 confluent (1)

- 50) ambulacral base parallel sided (0), strongly flared abradially (1)

- 51) external surface of oral ossicles evenly curved (0) with separate rounded rim and raised central area (1)

- 52) oral ossicle body elongated (0), square (1)

- 53) oral ossicles with short apophyse (0) elongated hypophysis (1)

- 54) apophyse angled to body (0), vertical, at right angles to actinal margin (1)

- 55) ring canal groove short (0), elongated, runs along length of proximal circumoral bar (1)

- 56) circumoral ossicle with long proximal circumoral process (0), short process (1)

- 57) uniform oral spines (0), discrete oral and suboral spines (1)

- 58) odontophore T-shaped in outline (0), semicircular (1)

- 59) odontopore actinal face smooth (0) with structures for articulation of chevron plates (1)

- 60)marginals large, block-like (0), tiny, form narrow flange (1), absent (2)

- 61) actinals present (0), absent (1)

- 62) actinals tile-like (0), elongated (1)

- 63) actinals with small spines (0), with large offset flattened thorny spines (1) 